\title{
Çankırı'da Günümüze Ulaşamayan Bir Eğitim Yapısı: Ertuğrul Mektebi
}

\author{
Education Building that has not Reached Today in Çankırı: Ertuğrul Mektebi
}

\section{Remzi Aydın* ${ }^{*}$}

\section{Öz}

Osmanlı reform hareketlerinin 19. yüzyılda yoğun olarak görüldüğü alanlardan biri de eğitim sistemidir. Maarif-i Umumiye Nezaretinin kurulması ve maarif teşkilatının taşrada yapılanmasıyla eğitimin tabana yayılması hedeflenmiştir. Özellikle Sultan II. Abdülhamid dönemi, devlet-vatandaş iş birliğiyle çok sayıda eğitim yapısının inşasının gerçekleştirildiği bir dönemdir. Bu yapılardan biri de Kastamonu Vilayeti’ne bağı Çankırı Sancağı'nda inşa edilip günümüze ulaşmamış olan Ertuğrul Mektebi'dir. Bu çalışmada, daha önce herhangi bir çalışmaya konu olmamış Ertuğrul Mektebi'nin inşa süreci ve mimari özellikleri ele alınarak, yapının geç dönem Osmanlı mimarlık ürünleri arasındaki yeri ve önemi ortaya konmuştur.

Literatür araştırması ve saha çalışması üzerinden gerçekleştirilen çalışmada Osmanlı Arşivi'nden temin edilen yazışma, kat ve cephe çizimleriyle harita gibi belgeler ve yapıya ait eski fotoğraflar vasıtasıyla günümüze ulaşmayan yapının inşa süreci, plan ve mekân tasarımı, cephe özellikleri ve yapıda kullanılan malzemeler tespit edilmiştir. Ayrıca, Çankırı Müzesi envanterine kayıtlı iki kitabenin Ertuğrul Mektebi'ne ait olduğu ispat edilmiş ve yapının kaynaklarda belirtilenin aksine Abdulvahab Paşa tarafından değil, Hasan Feham Paşa tarafından H.1309 (M.1892) yılında inşa ettirildiği kesinleştirilmiştir.

\section{Anahtar Kelimeler}

Eğitim, Çankırı, İbtidai, Rüşdiye, İdadi

\section{Abstract}

One of the areas in which Ottoman reform movements were intensively seen in the $19^{\text {th }}$ century was the educational system. With the establishment of the Ministry of Education (Maarif-i Umumiye Nezareti) and the organization of education in the provinces, it was aimed to spread the education to grassroots. Particularly, in the period of Sultan Abdülhamid II, many educational structures were built with state-citizen cooperation. One of these structures was the Ertuğrul Mektebi, built in the Çankırı Sanjak of Kastamonu Province. In this study, the construction process and architectural features of Ertuğrul Mektebi, which has not been the subject of any study before, have been discussed and the place and importance of the structure among the late Ottoman architectural works have been revealed.

In this study, based on literature research and field work, the building process, plan and space design, façade features and materials were determined by means of old photographs and Ottoman archive documents such as correspondence, maps, and floor and façade drawings. Furthermore, two inscriptions registered in the inventory of Çankırı Museum are proven to have belonged to Ertuğrul Mektebi and contrary to some sources, it was confirmed that the school was built by Hasan Feham Pasha in 1892 (1309 H.), not by Abdulvahab Pasha.

\section{Keywords}

Education, Çankırı, Primary (Ibtidai), Secondary (Rüşdiyye), High school (Idadi)

* Sorumlu Yazar: Remzi Aydın (Dr. Öğr. Üyesi), Erciyes Üniversitesi, Edebiyat Fakültesi, Sanat Tarihi Bölümü, Kayseri, Türkiye. E-posta: raydin@erciyes.edu.tr ORCID: 0000-0003-3026-1394

Atıf: Aydin, Remzi. “Çankırı'da Günümüze Ulaşamayan Bir Eğitim Yapısı: Ertuğrul Mektebi.” Art-Sanat, 13 (2020) 27-51. https://doi.org/10.26650/artsanat.2020.13.0002 


\section{Extended Summary}

It is known that the reform movements that started with the Tanzimat (Imperial Edict of Gülhane) and Islahat Edicts (Edict of Reform) in the Ottoman Empire and that gained great speed in the 19th century were also reflected in the Ottoman education system and institutions. Especially the construction activities during the reign of Sultan Abdulhamid II are remarkable in terms of showing the scope and intensity of the implementation of these reforms. A large number of educational institutions were built with state-citizen cooperation during this period. One of these construction activities is the Ertuğrul Mektebi which was built in the Çankırı Sanjak of Kastamonu Province. In this study, the construction process and architectural features of Ertuğrul Mektebi, which has not been the subject of any study before, have been examined and the place and importance of the building among the late Ottoman architectural works have been revealed.

The study has been carried out through literature research and field work. With the research in the Ottoman Archive, documents such as correspondence, drawings and a map giving important information about the construction process and architectural features of the school, now extinct, have been obtained. The field work, based on archival documents and previous publications, has been carried out both in Çankırı Museum and in the area where the school was built. In the inventory of Çankırı Museum, two inscriptions giving the answers of questions about when and by whom the school was built have been detected.

The related documents in the Ottoman Archive reveal that the Ertuğrul Mektebi was built in 1892 by Hasan Feham Pasha, the former Governor of Çankırı Sanjak. They also provide the information that Sultan Abdulhamid II named the school 'Ertuğrul Mektebi', in memory of Ertugrul Gazi and ordered to allocate 1500 kuruş from his personal budget to be used in year-end ceremonies.

Among the archival documents is a sketch, on a map with direction and scale, which is important in terms of showing the settlement plan of Ertuğrul Mektebi. According to this sketch, the entrance to the school is provided from the east and west sides. The lower and upper floor plans of the building and the façade view drawings give information about the architecture of the building which was a two-story building with a basement. The scale under the drawing of the façade makes it possible to calculate the height of the structure. The façade drawing shows that at the entrance was a three-span portico formed by four columns with Doric capitals connected to each other by depressed arches. The central arch was wider and higher and the separation of the stories was marked by a cornice around the building. A dynamic façade with plastic effect was created with protruding depressed arches, keystones and frames of the windows along with cornerstones at the corners and overhangs. Also, in the facade drawing, the monogram of Sultan Abdulhamid II was placed below the cornice and a 
two-line inscription was above the entrance door. The area of the building can be calculated by means of the scale under the floor plan drawings of the structure. Although the drawings do not provide any information about the functions of the spaces, it is understood that the spaces with a rostrum and seats and the ones with toilet stones and sinks, all drawn with dashed-straight lines in red ink, were to be used as classrooms and toilets respectively. It is noteworthy that the lower and upper floors were generally planned symmetrically.

Since the building has not reached today, the extent to which this project prepared for Ertuğrul Mektebi was implemented has been determined by comparing the old photographs of the building with the floor plans and facade drawings. The statements in the archive documents indicating that the construction process was finished have been confirmed by two inscriptions in the Çankırı Museum. Two inscriptions registered at the Çankırı Museum with the inventory numbers of 1077 and 1078 have been determined that they belonged to Ertuğrul Mektebi. These inscriptions have determined that, contrary to the sources stated that it was built by Abdulvahab Pasha, the school was built by Hasan Feham Pasha, the Governor of Çankırı Sanjak, in 1892 $(1309$ H.). Also in the inscription texts, the importance given to education by the Sultan and efforts of the bureaucrats in the field of education were emphasized.

Since the 'building book' has not yet been identified in the Ottoman Archives documents and the building is not extant, its architectural features have been evaluated with the help of the old photographs and the drawings of floor plans and façade. The main material used in the exterior of the building is cut stone. The colonnade columns on the front facade were likely to be marble-stone, and the ceiling was likely to be wood in accordance with the region and the period in which it was built. According to the floor plan drawings, the spaces in the building were arranged on both sides of the corridor in the middle. It is possible to see examples of schools built with this corridor-based plan scheme in the provinces as well as in the capital Istanbul. This scheme was used not only in schools, but also in different types of buildings such as government offices, prisons and military buildings. In terms of facade features, Ertuğrul Mektebi displayed the features of the neo-classical style, the common architectural style of the period. The symmetry in the plan design of the building was also reflected on the exterior. The protruding architectural elements, band course and cornice seen on all sides of the building and the monogram on the overhang were consistent with the characteristics of the buildings of the period of Sultan Abdülhamid II. It is possible to deduce from the buildings of the period that almost all public buildings had a certain style of unity on their façades as well as their plans. In this study, the architectural features of Ertuğrul Mektebi, built in parallel with the reforms of the Ottoman Empire in the field of education in the provinces, have been revealed in the light of the information obtained from the archives and fieldwork. 


\section{Giriş}

Osmanlı modernleşmesinin temel taşlarından biri de şüphesiz eğitim alanında gerçekleştirilen reformlardır. Osmanlı reform hareketlerinin yoğunlaştığı 19. yüzyılda, her alanda olduğu gibi eğitim sisteminde de değişim ve dönüşüm faaliyeti içerisine girilmiştir. Tanzimat ile başlayan süreçte eğitim alanı yeniden yapılandırılmış yeni kurumlarla işleyişine dair pek çok düzenleme gerçekleştirilmiştir. Bu kurumların başında eğitime yön verecek olan Maarif-i Umumiye Nezaretinin kurulması gelmektedir. Sonraki süreçte muhtelif tarihlerde eğitim sisteminin esaslarının belirlendiği Maarif Nizamnameleri çıkarılmıştır. ${ }^{1}$ Tanzimat aydınları ve bürokratları eğitim olmaksızın yapılan reformların eksik kalacağına inanmışlardır. ${ }^{2}$ Buna kani olan yöneticiler görev alanlarında eğitimin yaygınlaştırılması için yoğun çaba göstermişlerdir. Sultan II. Abdülhamid döneminde eğitim alanındaki gelişmeler oldukça hızlanmıştır. Hızlı gelişimin sebebi "eğitim sistemi ile devletin bekasının sekteye uğramadan devam ettirilmesi, yani otoritenin dönüştürülmek istenmesi" "3 ile tüm tebaaya Osmanlll1k duygu ve düşüncesinin ilköğretimden başlanarak verilmesine bağlanmaktadır. Böylelikle toplumun tüm kesimlerinin birlik ve bütünlüğ̈̈nün sağlanması hedeflenmiştir. ${ }^{4}$ Maarif teşkilatının taşrada yapılanması, eğitimin tabana yayılması bakımından atılmış en önemli adımdır. ${ }^{5} 1881$ yllından itibaren "usul-i cedid" üzere modern eğitimin verileceği mekatib-i ibtidai, mekatib-i rüşdiyye gibi ilköğretim okullarının tesisine ağırlık verilmeye başlanmıştır.

Maarif teşkilatının kazalara kadar yapılandığı yerlerden biri de Kastamonu Vilayeti'ne bağlı Çankırı Sancağı'dır. Bu yapılanmanın bir göstergesi olarak 1892 yılında Çankırı'da Maarif Meclisi kurulmuştur. ${ }^{6}$ Çankırı'nın eğitim durumu hakkında bilgiler sunan az sayıdaki çalışmadan, 19. yüzyılın ikinci yarısından sonra eğitim yapılarının inşasında belirgin bir hızlanma olduğu görülmektedir. Kastamonu Vilayet Salnamesi 'nin muhtelif sayılarında Çankırı'daki usul-i cedid üzere eğitim veren okul sayıları ve türleri 1869-1882 yılları arasında bir rüşdiyye, 1889 'da bir rüşdiyye ve iki ibtidai, 1892'de bir rüşdiyye ve bir ibtidai, 1893-1894 arasında bir idadi ve bir ibtidai, 1896'da bir idadi, iki ibtidai ve bir inas mektebi, 1899'da bir idadi ve bir ibtidai, 1903 ’teyse bir idadi ve üç ibtidai olarak zikredilmiştir. ${ }^{7}$ Mektep sayısı, ilk defa Feham

1 Konu hakkında detaylı bilgi için bkz. Osman Nuri Ergin, Türk Maarif Tarihi (İstanbul: Eser Kültür Yayınları, 1977); Teyfur Erdoğdu, "Maarif-i Umumiyye Nezareti Teşkilatı I," Ankara Üniversitesi Siyasal Bilgiler Fakültesi Dergisi 51/1 (1996), 183-247; Teyfur Erdoğdu, "Maarif-i Umumiyye Nezareti Teşkilatı II," Ankara Üniversitesi Siyasal Bilgiler Fakültesi Dergisi 52/1 (1997), 247-285.

2 Erdoğdu, "Maarif-i Umumiyye Nezareti Teşkilatı I," 196.

3 Erdoğdu, "Maarif-i Umumiyye Nezareti Teşkilatı I," 212.

4 Bayram Kodaman, Abdülhamid Devri Eğitim Sistemi (Ankara: Türk Tarih Kurumu Yayınları, 1999), 69.

5 Kodaman, Abdülhamid Devri, 37-56.

6 Kodaman, Abdülhamid Devri, 48.

7 Ömer Türkoğlu, Sâlnâmelerde Cankırı (Cankırı: Cankırı Valiliği Yayınları, 1999), 12, 35, 59, 86, 11, 134, $161,186,211,231,249,262,281,305,331,367,395-396,432,461,503-504,532-533$. 
Hasan Paşa'nın mutasarrıf olduğu 1889 yılında artış göstermiştir. ${ }^{8}$ Ele alınan Ertuğrul Mektebi'nin adınaysa salnamelerde ilk defa 1893 y1lında rastlanmaktadır. ${ }^{9}$

$\mathrm{Bu}$ çalışmada, Çankırı'da yeni usulde eğitim vermek üzere inşa edilen Ertuğrul Mektebi ele alınmıştır. Günümüze ulaşamayan yapıyla ilgili olarak şimdiye kadar doğrudan bir çalışma yapılmamıştır. Yapının mimari özelliklerine sadece tek bir çalışmada yüzeysel olarak değinilmiştir. ${ }^{10}$ Çankırı' daki tarihi yapıların incelendiği bir diğer çalışmadaysa yapıya ait kitabeler, farklı bir binaya ait olarak ele alınmıştır. ${ }^{11}$ Çankırı'ya ait eski fotoğraflardan meydana getirilen bir başka çalışmada yapının bir fotoğrafiyla geçirdiği yangın ve yıkım tarihine dair kısa bilgiye yer verilmiştir. ${ }^{12}$ Çankırı eğitim tarihiyle ilgili yayınlarda yapıdan dolaylı olarak söz edilmektedir. ${ }^{13}$ Çalışma neticesinde şimdiye kadar herhangi bir çalışmaya doğrudan konu edilmemiş olan Ertuğrul Mektebi'nin inşa süreci ve mimari özellikleri değerlendirilmiş ve geç dönem Osmanlı eğitim yapıları arasındaki yeri ortaya konmaya çalışılmıştır. Bu doğrultuda, Osmanlı Arşivinde tespit edilen yazışma, çizim ve kroki gibi belgelerle yapıya ait eski fotoğraflar üzerinden günümüze ulaşmayan yapının inşa süreci, plan ve mekân tasarımı, cephe özellikleri ve yapıda kullanılan malzemeler ortaya çıkarılmıştır. Ayrıca belgeler ve Çankırı Müzesi'nde bulunan kitabeler vasıtasıyla yapının inşa tarihiyle yapımına katkıda bulunanlar tespit edilmiştir.

\section{Tarihi Süreçte Ertuğrul Mektebi}

Osmanlı Arşivinde tespit edilen belgelerin içeriklerinden Ertuğrul Mektebi'nin, Tanzimat sonrasında ortaya çıkan, kademeli eğitim sisteminin her bir basamağında, ibtidai, rüşdiyye ve idadi mektebi olarak hizmet verdiği anlaşılmaktadır.

Çankırı'da inşa edilen mekteplere dair en erken tarihli yazışmalar, 1868 yılına aittir. 19 Ağustos 1868 tarihli belge, Daday ve Çankırı'da inşa edilen iki rüşdiyye mektebi için gereken kitaplarla muallimlerin atamasına ilişkindir. ${ }^{14} 12$ Ekim 1868 tarihinde Çankırı Mutasarrıfı Mahmud İskender Bey tarafından Kastamonu Valiliğine gönderilen yazıda, sultanın cülus yıldönümü münasebetiyle vilayet, liva, şehir ve kasabalarda inşası talep edilen rüşdiyye mekteplerinden birinin de Çankırı' da yaptırıldığı bildi-

8 Türkoğlu, Sâlnâmelerde Çankırı, 325, 331.

9 Türkoğlu, Sâlnâmelerde Çankırı, 395.

10 Mine Topçubaşı, “19. Yüzyılda Kastamonu Eyaleti’nde Kamu Yapıları ve Yeniden Kullanım Sorunları” (Doktora tezi, İstanbul Teknik Üniversitesi, 2009), 329.

11 Betül Özcan Balkır, “Çankırı (Merkez İlçe ve Köyleri) Türk Dönemi Mimari Eserleri” (Doktora tezi, Gazi Üniversitesi, 2018), 548-550.

12 Aydın Demiröz, 1893-1969 Fotoğraflarla Çankırı (Çankırı: Çankırı Belediyesi Kültür Yayınları, 2001$), 42$.

13 Galip Eken, “19. Yüzyılda Sonlarında Çankırı'da Eğitime Dair”, Cumhuriyet Üniversitesi Edebiyat Fakültesi Sosyal Bilimler Dergisi 37/1 (2013), 107-116; Cahit Aktaş, "Belgeler Işı̆̆ında Kengırı (Çankırı) Kız Mektebi," Çankırı Araştırmaları Dergisi 3 (2008), 73-84.

14 Başbakanlık Osmanlı Arşivi (BOA), Sadaret Mühimme Kalemi Evrakı (A.MKT.MHM.) 417/16, 29 Rebiülahir 1285 (19 Ağustos 1868). 
rilmiştir. Bahsi geçen okula kırktan fazla öğrencinin kaydedilerek eğitime başlandığı ifade edilmiş ve başta sultan olmak üzere katkıda bulunanlara teşekkür edilmiştir. ${ }^{15} 29$ Ekim 1868 tarihinde Kastamonu Valiliğinden Sadaret'e hitaben kaleme alınan yazıda, sultanın tahta çıkış yıldönümü şerefine Çankırı'da inşa ettirilen rüşdiyye mektebinin açılış töreninde padişaha dua edildiği ve gönderilen kitapların öğrencilere dağıtılarak eğitime başlandığı belirtilmiş̧tir. ${ }^{16} 10$ Kasım 1868 tarihli cevabi yazıyla Çankırı'daki rüşdiyye mektebinin inşasından duyulan memnuniyet Kastamonu Valiliği’ne bildirilmiştir. ${ }^{17}$

4 Aralık 1870 ve 13 Şubat 1871 tarihli belgeler, 1870 yılı içerisinde Çankırı'da gerçekleştirilen imar ve bayındırlık işleriyle ilgili hazırlanmış cetvellerin gönderildiğine dairdir. ${ }^{18}$

Yazışmalar arasında Ertuğrul Mektebi adına ilk defa 1892 yılında rastlanmaktadır. Eski Çankırı Mutasarrıfı Hasan Feham Paşa, 12 Haziran 1892 tarihinde Mabeyn-i Hümayun Baş Katipliği'ne gönderdiği yazıda, dört seneye yakın görev yaptığı şehrin eğitim durumunu eleştirel bir gözle değerlendirmiştir. Paşanın başlıca eleştirisi, eğitimin hâlâ eski tarzdaki sıbyan mekteplerinde gerçekleştirilmesine yöneliktir. İşte bu eleştiri doğrultusunda eğitimdeki eksiklikleri tamamlamak üzere harekete geçen Paşa, tedarik ettiği bütçe ve bağışlarla ibtidai ve rüşdiyye içeren bir okulun yapımına girişmiştir. Söve, sütun ve köşeleri som taştan tamamıyla kargir olarak inşa edilen bina, paşa tarafından çevrede eşi görülmeyen bir yapı olarak betimlenmiştir. Paşa, okul yararına 1500 kuruş vakfetmiş ve bu paranın nemasının (getiri-faiz) yılsonu merasimlerinin masraflarının karşılanmasında kullanılmasını şart koşmuştur. Bu törenlerde, başta İslam peygamberi olmak üzere evliya ve enbiya ruhlarına okunan hatm-i şerif duasıyla mevlid-i şerif icra edilecek ayrıca öğrencilere hediyeler verilecektir. Paşa ve sancak ahalisi inşa edilen okula sultanın ismi ve simgesinin (tuğra) konulmasını ve yapımda emeği geçen kişilerin nişan ve madalyalarla ödüllendirilmesini önermiş ve okula ait çizimleri göndermiş̧tir. ${ }^{19}$ Maarif Komisyonu başkanı Müftü Mustafa Hazım Efendi, İzmir paye-i mücerredi; Liva İdare Meclisi Azası Hasan Efendi, rütbe-i hame; Belediye Kalfası İsmail Usta, beşinci derece Mecidi nişanı; Müteahhid Mustafa Usta sanayi madalyasıyla ödüllendirilmesi önerilen kişilerdir. ${ }^{20}$

Paşa tarafından gönderilen evraklar içerisinde, bir çizim de yer almaktadır. Üzerinde tarih ibaresi yer almayan çizim, ön cephe görünüşüyle alt ve üst kat planlarından

15 Başbakanlık Osmanlı Arşivi (BOA), Sadaret Mühimme Kalemi Evrakı (A.MKT.MHM.) 426/30-4, 22 Receb 1285 (8 Kasım 1868).

16 BOA. A.MKT.MHM. 426/30-2, 3 .

17 BOA. A.MKT.MHM. 426/30-1.

18 Başbakanlık Osmanlı Arşivi (BOA), Şura-yı Devlet (ŞD.) 1640/1-1, 2, 24 Zilkade 1287 (15 Şubat 1871).

19 Başbakanlık Osmanlı Arşivi (BOA), İrade Dahiliye (İ.DH.) 1283/100985-3, 1 Zilhicce 1309 (27 Haziran 1832).

20 BOA. İ.DH. 1283/100985-2. 
meydana gelmektedir ${ }^{21}$ (G. 1). 26 Haziran 1892 tarihinde Yıldız Sarayı Başkatipliği Dairesi'nden kaleme alınan yazı, Feham Hasan Paşa tarafından gönderilen evrak ve eklerinin Sultan II. Abdülhamid'e sunulduğunu göstermektedir. Sultan, inşa edilen okula kendinin değil ecdadı Ertuğrul Gazi'nin adının verilmesini "cedd-i âlây-l hazret-i hilâfet-penâhî firdevs-âşiyan Ertuğrul Gazi hazretlerinin nam-ı celâdet-i ittisam-ı âlîlerine nisbetle tesmiye olunması "22 ifadesiyle buyurmuştur. Sultan ayrıca her sene yılsonu törenlerinde kullanılmak üzere şahsi bütçesinden 1500 kuruş tahsis edilmesini de emretmiştir. ${ }^{23}$ Sultanın kararları Sadrazam Cevad Paşa tarafından 28 Haziran 1892 tarihinde Kastamonu Vilayeti ile Maarif Nezaretine iletilmiştir ${ }^{24}$. Maarif Nezareti Mekatib-i Rüşdiyye İdaresi 16 ve 30 Temmuz 1892 tarihli yazısıyla, sultanın Çankırı'da rüşdiyye ve ibtidai olarak inşa edilen okulla ilgili aldığı kararını haber hâline getirilmesi için Dahiliye Nezareti Matbuat Dairesine bildirmiştir. ${ }^{25}$

1893-1897 yılları arasında geçen yazışmalarda, Ertuğrul Gazi Mektebi’nden dolaylı olarak söz edilmektedir. 1893 yılına ait yazışmalar, Dahiliye Nezareti, Kastamonu Valiliği ve Maarif Nezareti arasında geçmektedir. Yazışmaların konusunu, Çankırı'daki Ertuğrul Gazi Mektebi'nin kapasite bakımından idadi için yeterli olması ve bu sebeple de yapımına başlanıp yarıda kalan idadi binasının tamamlanıp farklı işlevlerde değerlendirilmesi oluşturmaktadır. ${ }^{26}$

1895 yılındaki yazışmalar, Ertuğrul Gazi Mektebi’nin idadi ihtiyacını karşılayabilecek kapasitede olmasından dolayı yarım kalan idadi binasının tamamlanıp hükümet konağı olarak kullandırılmasına dairdir. Bu yazışmalarda ileride öğrenci sayısının artma olasılığına karşı, ahalinin yardımlarıyla Ertuğrul Mektebi'nin iki tarafına dershane ilave edilip genişletilebileceği de ifade edilmiştir. ${ }^{27}$

1897 yılı yazışmaları Ertuğrul Mektebi ile yarım kalan idadi binasının inşa edildiği arsanın, fazla kısmının nasıl değerlendirileceğine yöneliktir. Konuya ilişkin hazırlanan, yönü ve ölçeği belirtilmiş harita üzerine iki mektep binasıyla arsanın satışa çıkacak kısmı ölçüleriyle işlenmiştir (G. 2). Arsanın fazla kısmıyla ilgili iki seçenek gündeme gelmiştir. Birinci seçenekte arsa satılacak, ikinci seçenekteyse üzerine han, dükkân ve hane inşa edilerek kira getirisi sağlanacaktır. Her iki seçenekten elde edilecek gelirlerse Tevfikiye ve Feyziye ibtidailerinin ihtiyaçlarının karşılanmasıyla bir kız

21 BOA. İ.DH. 1283/100985-1.

22 Mekânı cennet olan yiğitliğiyle nam salmış büyük atam Ertuğrul Gazi hazretlerinin adının verilmesi.

23 BOA. İ.DH. 1283/100985-4.

24 Başbakanlık Osmanlı Arşivi (BOA), Maarif Nezareti Mektubi Kalemi (MF.MKT.) 146/29-1, 6 Muharrem 1310 (31 Temmuz 1892).

25 BOA. MF.MKT. 146/29-2, 3.

26 Başbakanlık Osmanlı Arşivi (BOA), Dahiliye Mektubi Kalemi (DH.MKT.) 121/33-1, 2, 3, 4, 7 Rebiülahir 1311 (18 Ekim 1893).

27 Başbakanlık Osmanlı Arşivi (BOA), Dahiliye Mektubi Kalemi (DH.MKT.) 347/39-13, 14, 26 Şaban 1312 (22 Şubat 1895). 
ibtidaisinin yapılmasına harcanacaktır. ${ }^{28}$ Belgeler içerisinde yer alan harita, Ertuğrul Mektebi’nin cephe yönlerinin belirlenmesi bakımından ayrı bir öneme sahiptir.

1901 yılına ait yazışmalar, Ertuğrul Mektebi'nin çatı onarımına ilişkindir. 28 Nisan 1901 tarihinde Çankırı Belediye Kalfası İsmail Hakkı Bey'in hazırladığı keşif varakasında, çatının onarım sebebi yapım sırasında kiremitlerde harç kullanılmaması dolayısıyla içeri giren kar ve yağmur sularının mahya kirişlerini bozması olarak açıklanmıştır. Varakada onarım için gereken malzemeler, miktarı, fiyatı ve işçilik ücretleri belirlenmiştir. Buna göre usta ve ameleler, kiremit, kum, kireç ve boru kullanarak onarımı gerçekleştirecektir. Keşif varakasına göre bu onarım 1140 kuruşa mal olacaktır. ${ }^{29} 26$ Mayıs 1901 tarihli münakasa kaimesinde 1140 kuruş üzerinden onarımın ihaleye çıkarılacağı ifade edilmiştir. İhale şartnamesine göre müteahhitlerden muteber bir kefil getirmeleri de istenmiştir. İhaleyi kazanan müteahhit, işin başında belirlenen ihale bedelinin yarısını, iş bittikten sonra yapılacak ikinci keşifte herhangi bir eksik tespit edilmezse diğer yarısını alacaktır. Tespit edilen eksiklerin tamamlanmasından müteahhit kadar kefili de sorumlu olacaktır. Ayrıca kullanılacak kiremit ve kireç gibi malzemelerin kaliteli olmasına da dikkat edilecektir. ${ }^{30}$ Ertuğrul Mektebi’nin müdürü tarafından Çankırı Mustasarrıflığı'na gönderilen 26 Mayıs 1901 tarihli yazıda, mektebin tamiri için gerekli malzemelerin daha önce tespit edilerek maarif müdürlügüne gönderildiği ve onarıma talip çıkmadığı ifade edilmiştir. ${ }^{31}$ Kastamonu Maarif Müdürlüğü Maarif Nezareti’ne gönderdiği 14 Eylül 1901 tarihli yazısıyla, mektebin tamiri için gereken 1140 kuruşun kullanımına dair izin talebinde bulunmuştur. ${ }^{32}$ Maarif Nezareti Muhasebe Dairesi 5 Ekim 1901 tarihli cevabi yazısında, bütçede bu yıl için para bulunmadığından başka bir çözüm bulunması gerektiğini Maarif Nezareti’ne bildirmiştir. ${ }^{33}$ Maarif Nezareti de bütçeden para tahsis edilemeyeceğini 26 Ekim 1901 tarihinde Kastamonu Vilayeti Maarif Müdürlüğü’ne iletmiştir. ${ }^{34}$

Ertuğrul Mektebi’nin inşa ve onarımlarıyla ilgili Osmanlı Arşivinde tespit edilebilen yazışmalar, 26 Ekim 1901 yılı itibariyle kesilmektedir.

\section{Ertuğrul Mektebi’nin Mimari Özellikleri}

Osmanlı Arşivinde Ertuğrul Mektebi olarak adlandırılan bina, sonraki yıllarda Kurtuluş Kız Mektebi ve Kurtuluş İlkokulu adıyla kayıtlarda yerini almıştır. Günümüze

28 Başbakanlık Osmanlı Arşivi (BOA), Maarif Nezareti Mektubi Kalemi (MF.MKT.) 365/3-1, 2, 2a, 3, 10 Rebiülevvel 1315 (9 Ağustos 1897).

29 Başbakanlık Osmanlı Arşivi (BOA), Maarif Nezareti Mektubi Kalemi (MF.MKT.) 587/53-1, 11 Receb 1319 (24 Ekim 1901).

30 BOA. MF.MKT. 587/53-2.

31 BOA. MF.MKT. 587/53-3.

32 BOA. MF.MKT. 587/53-4.

33 BOA. MF.MKT. 587/53-4a.

34 BOA. MF.MKT. 587/53-1. 
ulaşamayan okuldan geriye birkaç eski fotoğrafla müzede tespit ettiğimiz inşa kitabeleri dışında herhangi bir kalıntı bulunmamaktadır. 10 Mart 1945 tarihinde bir yangına maruz kaldığı eski bir fotoğrafın üzerine düşülen nottan anlaşılan yapı yıktırılmış ve yerine 1947 yılında yeni bir okul binası yaptırılmıştır. ${ }^{35} \mathrm{Bu}$ sebeple yapının özgün mimari özellikleri şimdiye kadar herhangi bir çalışmaya konu edilmemiştir.

Cumhuriyet dönemi arşivlerinde herhangi bir veri bulunmadığından yapının mimari özellikleri hakkında bilgi edinilebilecek tek kaynak, şimdilik Osmanlı Arşivinde tarafımızca tespit edilen çizimdir (G. 1).

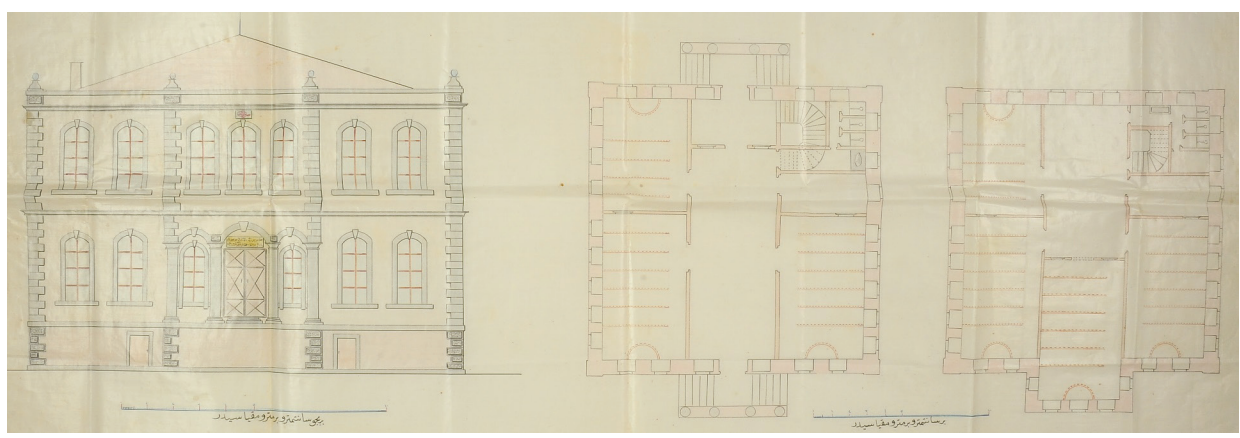

G. 1. Ertuğrul Mektebi'nin Ön Cephe Görünüşü ile Alt ve Üst Kat Planları (BOA. İ.DH. 1283/100985-1).

Üzerinde tarih bulunmayan çizim, içerisinde bulunduğu dosyadaki diğer evraklarla (12 Haziran 1892/30 Temmuz 1892) aynı zaman dilimi içerisinde hazırlanmış olmalıdır. Belgelerde "resim" olarak zikredilen çizim, okulun alt ve üst kat planlarıyla ön cephe görünüşünden oluşmaktadır. Kim tarafından hazırlandığına dair bir kaydın yer almadığ 1 çizim üzerinde, yön belirten herhangi bir işaret bulunmamaktadır. Çizim üzerinde yer alan çizik ölçeğe göre, cephe görünüşünde $1.5 \mathrm{~cm} .1 \mathrm{~m} .{ }^{\prime} \mathrm{ye}^{36}$, planda ise $1 \mathrm{~cm} .1 \mathrm{~m}$.' $\mathrm{ye}^{37}$, karşılık gelmektedir. Ölçek altyazıları hariç çizimlerin üzerinde mekânların işlevini açıklayıcı herhangi bir yazı yer almamaktadır. Ancak mekânlar içerisine işlenmiş çeşitli unsurlar, mekânların işlevinin anlaşılmasını mümkün kılmaktadır. Buna göre planlar üzerine kırmızı renk mürekkeple kesik ve düz çizgilerle kürsü ve sıraların işlendiği mekânların sınıf olduğu anlaşılmaktadır. Bunun dışında hela taşları ve lavaboların işlendiği kısımların tuvalet olduğu tespit edilebilmektedir. Cephe görünüşü yapının kat sayısını vermesinin yanı sıra giriş kapısı üzerine işlenen kitabe, metnindeki ebced ile düşülmüş inşa tarihini belirtmesi bakımından ayrı bir öneme sahiptir. ${ }^{38}$

35 Demiröz, 1893-1969 Fotoğraflarla Çankırı, 42; Topçubaş1, “19. Yüzyılda Kastamonu Eyaleti’nde Kamu Yapıları ve Yeniden Kullanım Sorunları," 329.

36 "Bir buçuk santimetro bir metro mikyasıdır."

37 "Bir santimetro bir metro mikyasıdır."

38 BOA. İ.DH. 1283/100985-1. Çizim üzerindeki kitabe metni ve ebced hesaplaması yapıya ait müze envanterine 1077 numarayla kayıtlı kitabeyle karşılaştırma yapılarak sonraki bölümde değerlendirilecektir. 
Yap1 kütlesinin arsa üzerinde nasıl konumlandığ1 çizim üzerinde yön işareti bulunmamasından dolayı bilinmemektedir. Ancak hem Ertuğrul Mektebi hem de yarım kalan idadinin inşa edildiği arsanın fazla kısmının satışı için hazırlanmış olan 1897 tarihli harita üzerine işlenen binanın krokisi oturum vaziyetini ortaya koymaktadır (G. 2). Haritada belirtilen sınırların günümüzde de değişmediği uydu görüntülerinden anlaşılmaktadır (G. 3).

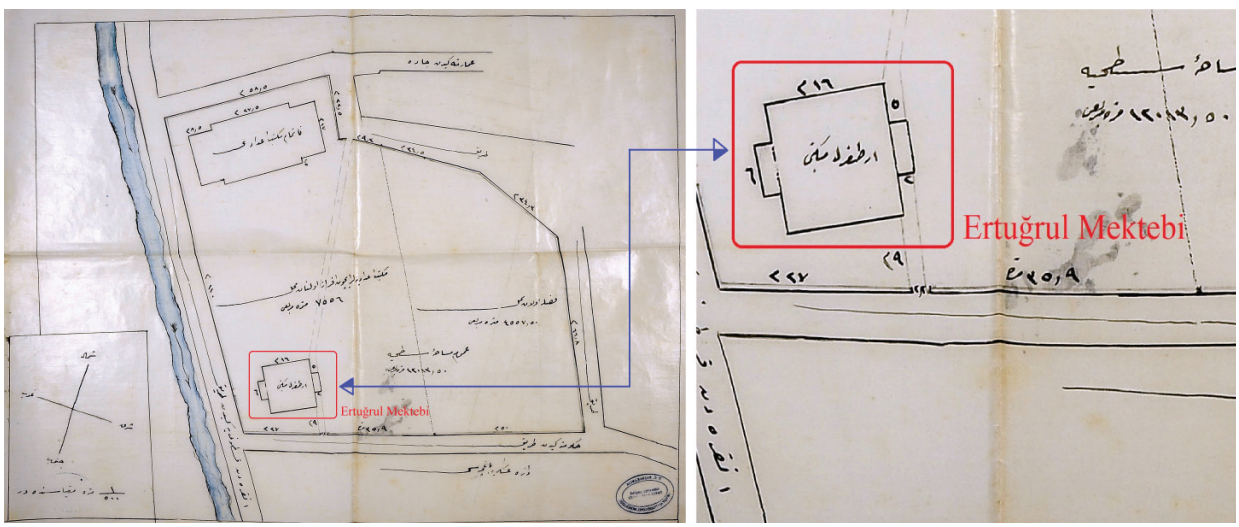

G. 2. Ertuğrul Mektebi’nin Krokisini İçeren Harita ve Detay1 (BOA. MF.MKT. 365/3-1).

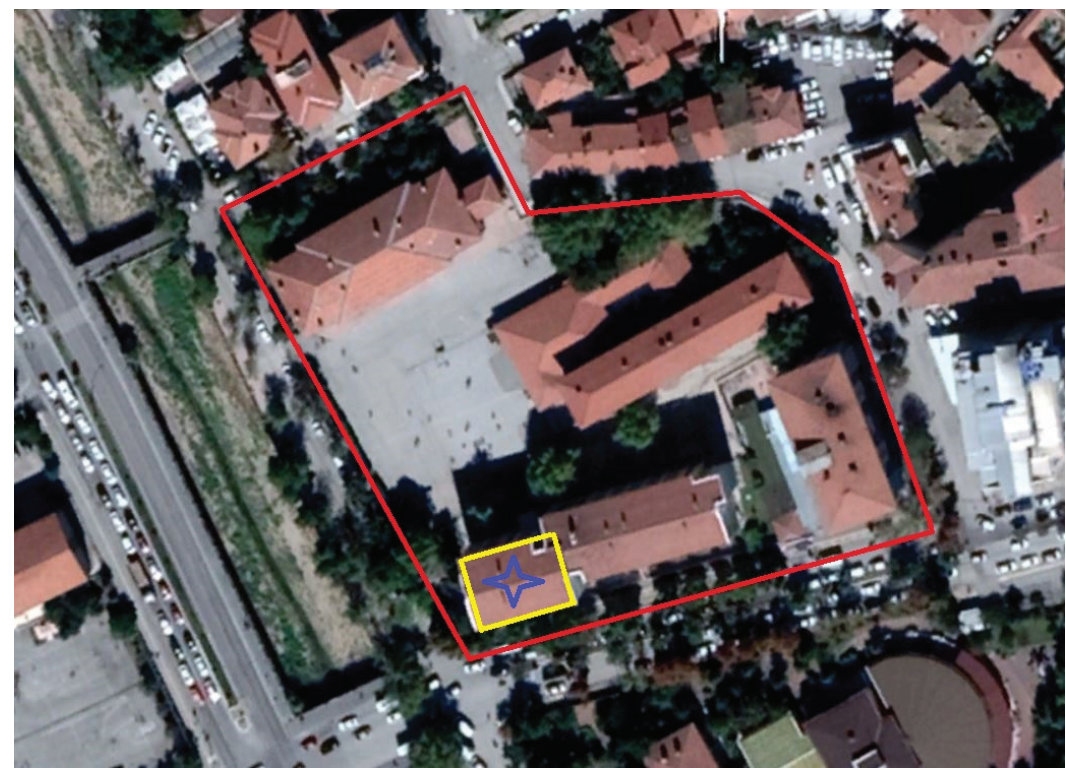

G. 3. Yıkılan Ertuğrul Mektebi’nin Bulunduğu Alanın Güncel Uydu Görünümü (40.36200 K, 33.364827 D Google Earth Pro Uygulamasindan).

Harita üzerindeki krokiden hareketle mektebin girişlerinin bulunduğu ön ve arka cephelerinin doğu-batı, yan cephelerin ise kuzey-güney yönde olacak şekilde konumlandırıldığı anlaşılmaktadır. Aynı harita üzerindeki günümüze ulaşan idadi binasının 
ön cephesinin sokağa bakmasından yola çıkılarak Ertuğrul Mektebi'nin ön cephesinin de batısındaki yola nazır olduğunu söylemek mümkündür.

Harita üzerinden yapılan yukarıdaki çıkarımlar, Ertuğrul Mektebi’nin yön belirtilerek tanımlanmasını mümkün kılmaktadır (G. 4, G. 5). 16x16 m. ölçülerinde kare bir kütleye sahip olan yapıya giriş, doğu ve batı cephelere yerleştirilmiş kapı açıklıklarından sağlanmaktadır. Girişlerin önüne çift yönlü merdivenlerle ulaşılan, dörder sütunla taşınan revaklı sahanlık yerleştirilmiştir. Küçük farklılıklarla alt ve üst kat planları simetrik bir düzen sergilemektedir. Her iki katta da planın belirleyici unsuru doğubatı doğrultusunda uzanan koridordur. Alt katta, koridorun kuzeybatı, kuzeydoğu ve güneybatısında birer olmak üzere üç derslik bulunmaktadır. Güneybatı dersliğinin bitişiğindeki mekân, muhtemelen okul yönetimine ayrılmış (müdür-muallim) bir oda olmalıdır. Bu odanın bitişiğinde alt kata ait ön bölümünde lavabolu üç bölümlü hela bulunmaktadır. Koridorun doğu ucu bir bölme duvarıyla ayrılmıştır. Bu bölümün güneydoğu köşesine yerleştirilmiş merdivenle üst kata ulaşıllmaktadır (G. 4).

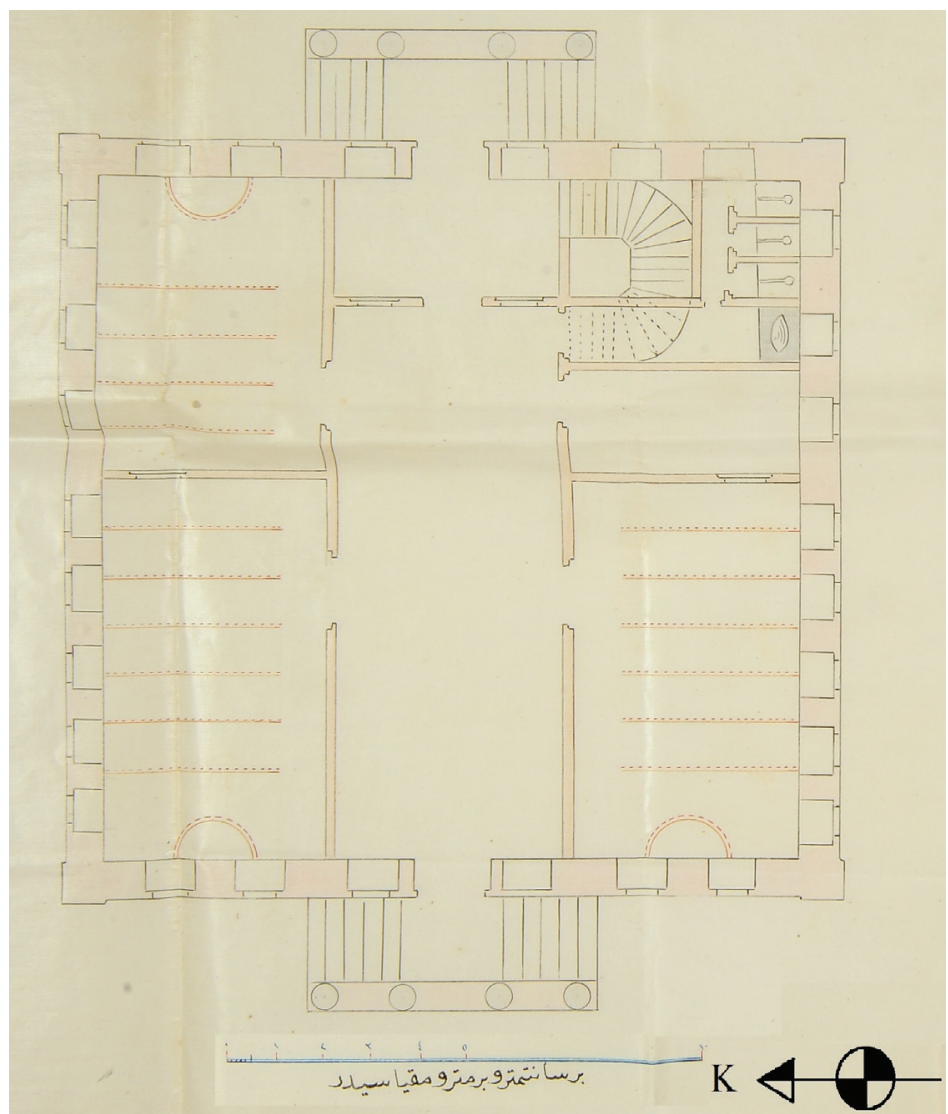

G. 4. Alt Kat Plan1 ${ }^{39}$ (BOA. İ.DH. 1283/100985-1).

39 Çizim üzerindeki yön işareti haritadan yapılan çıkarımlar neticesinde işlenmiştir. Çizimler, daha iyi anlaşılabilmesi için kesilmiş ve planlar için ortak hazırlanan ölçek, boyutları bozulmadan her iki plana da aktarılmıştır. 
Üst kat ile alt kat arasında küçük farklılıklar göze çarpmaktadır. Başlıca farklılık, koridorun düzenleniş biçimidir. Üst katta, alt katın batısındaki revak alanının değerlendirilmesi sonucu bir genişletme söz konusudur. Genişletilen alan iç kısımda koridorun ortasına ilave edilen bir bölme duvarı ile derslik haline getirilmiştir. Böylelikle alt katta üç olan derslik sayısı, üst katta dörde yükselmiştir. Bir diğer fark ise üst kata çıkışın sağlandığı merdiven kovasının yerleştirilmesinden kaynaklı olarak üst kat helasının giriş yeri ve lavabosunun yer değiștirmesidir. Bunun dışındaki bölümlerde bir farkl1lık görülmemektedir. Her iki katta koridora bağlı mekân kurgusuyla konut mimarisindeki iç sofalı plan tipini sergilemektedir (G. 5).

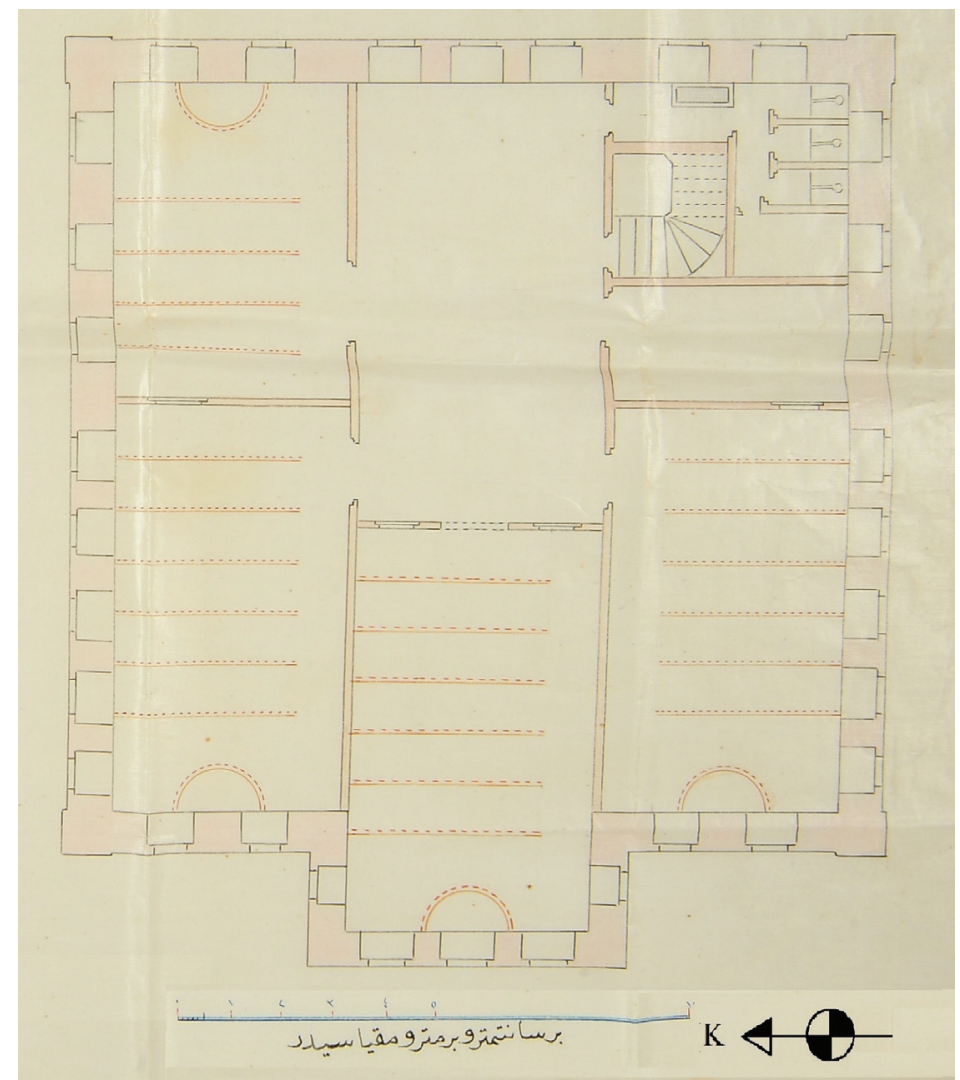

G. 5. Üst Kat Plan1 ${ }^{40}$ (BOA. İ.DH. 1283/100985-1).

Cephe çiziminden öncelikli olarak yapının bodrum katının da bulunduğu anlaşı1maktadır. Ancak bodrum katın planına çizimde yer verilmemiştir. Çizimin altındaki ölçekten hareketle bodrum katın yaklaşık $2.5 \mathrm{~m}$. alt ve üst katların ise $6 \mathrm{~m}$. yükseklikte olduğu tespit edilmektedir. Saçak seviyesine kadar yapının toplam yüksekliği 15 m.

40 Çizim üzerindeki yön işareti haritadan yapılan çıkarımlar neticesinde işlenmiştir. Çizimler, daha iyi anlaşılabilmesi için kesilmiş ve planlar için ortak hazırlanan ölçek, boyutları bozulmadan her iki plana da aktarılmıştır. 
civarındadır. Cephedeki profilli silme kuşakları, kat ayrımlarını belirtecek şekilde vurguludur. Cephedeki simetrik kurgunun odağını dışa doğru taşırılan giriş revakı oluşturmaktadır. Birbirine basık kemerlerle bağlanan, dor başlıklı dört sütun tarafından taşınan revak, üç açıklıklı düzeni meydana getirmektedir. Ortadaki açıklık daha geniş tutularak giriş kapısının görünürlüğü artırılmıştır. Pencerelerin basık kemeri, kemer kilit taşı ve söveleri dışa doğru taşırılmış ve cepheye hareket kazandırılmıştır. Cephelerin birleşim noktalarıyla çıkmanın kenarlarına konan dışa taşkın köşe taşları plastik etkiyi artıran bir başka unsurdur. Arkasındaki çatıyı gizleyen parapetin üzerine ikisi ortada, ikisi köşelerde olmak üzere dört baba taşı yerleştirilmiştir. Cephede, saçak silmesinin altına Sultan II. Abdülhamid'in tuğrası işlenmiştir. Giriş kapısının üzerine ise iki satır hâlinde kitabe metni yazılmıştır. Ebced ile tarih düşürülen kitabe metninde "Gelüb üçler didi itmamına tarih-i cevherdar / beşâret olsun etfale yapıldı mekteb-i rana" yazilidır (G. 6) ${ }^{41}$.

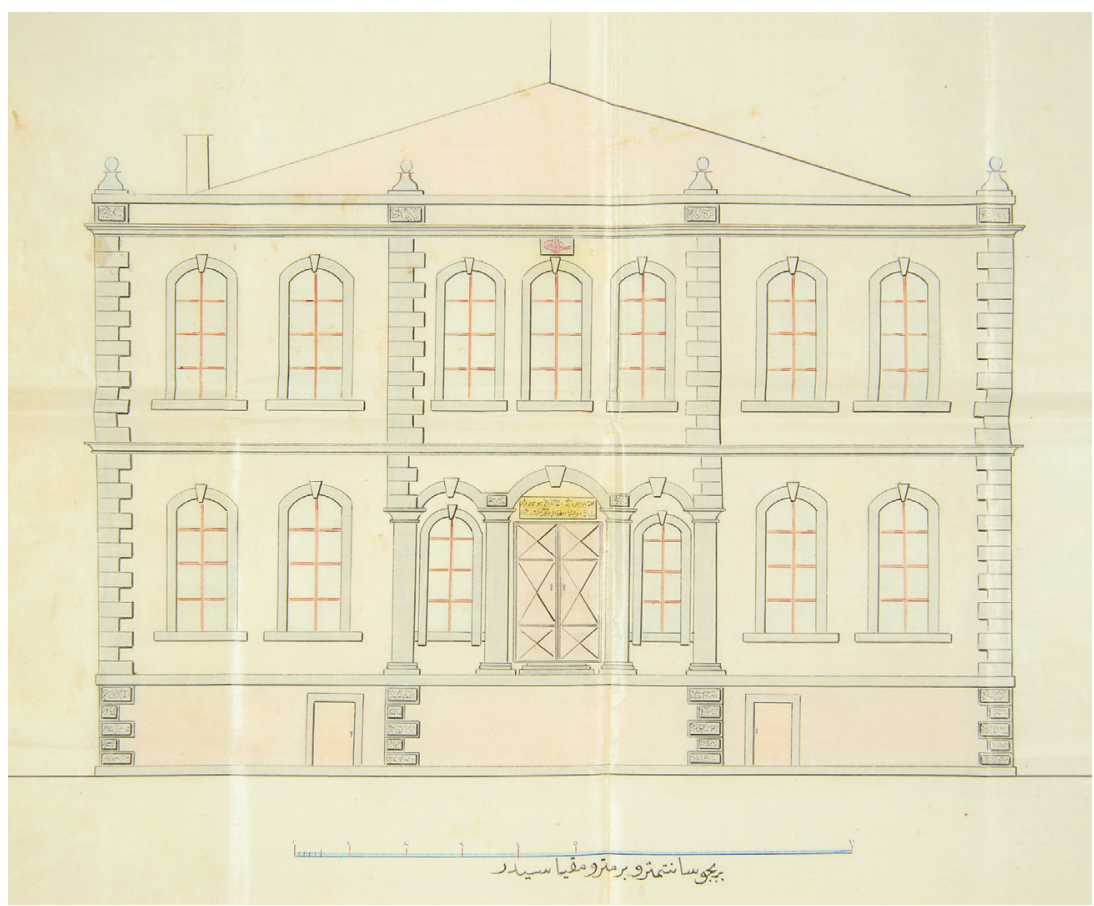

G. 6. Cephe Görünüşü² (BOA. İ.DH. 1283/100985-1).

Ertuğrul Mektebi için hazırlanan projenin uygulandığı eski fotoğraflardan anlaşılmaktadır. Ancak projenin ne kadarının uygulandığ sorusunun yanıtını tam olarak verebilmek yapının günümüze ulaşmamış olması sebebiyle mümkün değildir. Ancak

41 BOA. İ.DH. 1283/100985-1. Kitabe metnindeki ifadelerden hareketle yapılan ebced hesaplamasında inşa tarihi H. 1309 tarihine (1891-1892) tekabül etmektedir. Müze envanterinde 1077 numarayla kayıtlı kitabenin son satırı ile çizime işlenen metin birebir aynı olduğundan ebced hesaplamasının detayı kitabenin transkripsiyonuyla ilgili bölümde zikredilecektir.

42 Cephe görünüşü daha iyi anlaşılabilmesi için kesilmiştir. 
yapıya dair elde kalan birkaç eski fotoğraf bazı sorulara cevap vermektedir. Yapıya ilişkin bilinen en eski fotoğraf Sultan II. Abdülhamid tarafından hazırlatılan albümde yer almaktadır. Üstünde tarih bulunmayan fakat katalog kaydında 1888-1893 arasında basıldığı belirtilen bu fotoğraf, çerçevesindeki yazıya göre İstanbul'daki Sebah \& Joaillier Fotoğraf Atölyesi'nde basılmıştır. Amerikan Kongre Kütüphanesi'nde 2001700265 numarayla kayıtlı fotoğrafin üst kısmında "Kengırı Mektebi İdadi-yi Mülkiyesi" yazılıdır. Ön ve yan cephenin çekildiği bu fotoğraftan arşiv çizimindeki cephe tasarımının parapet dışında tamamıyla uygulandığı anlaşılmaktadır. Hatta detay olarak ön cephedeki çıkmanın saçak altında bulunan ve çizimde kırmızı renkle vurgulanan dikdörtgen formlu tuğra levhasının dahi yerleştirilmiş olduğu seçilebilmektedir (G. 7, G. 8).

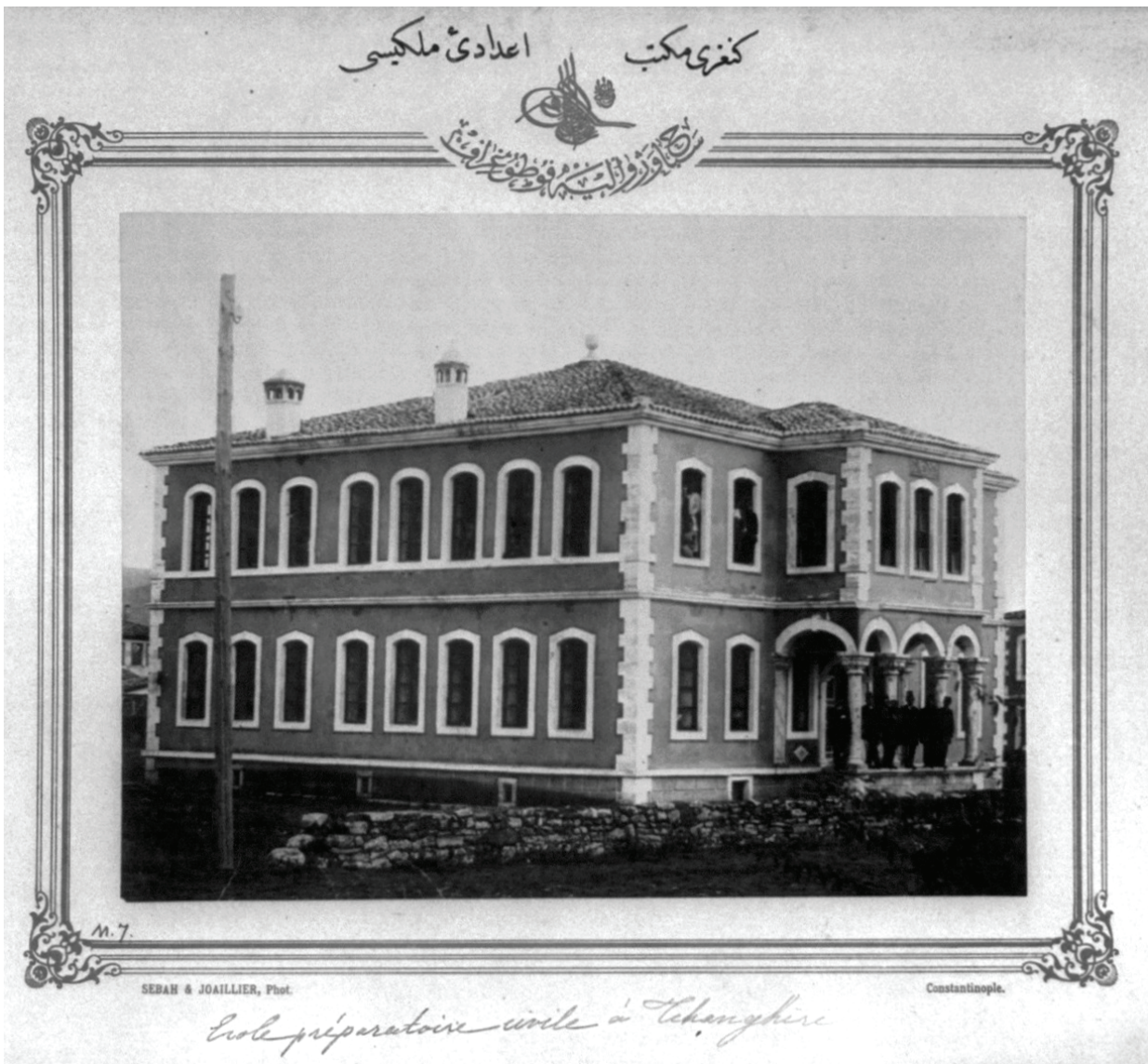

G. 7. Çankırı Mülkiye İdadi Mektebi (https://www.loc.gov/item/2001700265/ erişim 12.08.2019) 


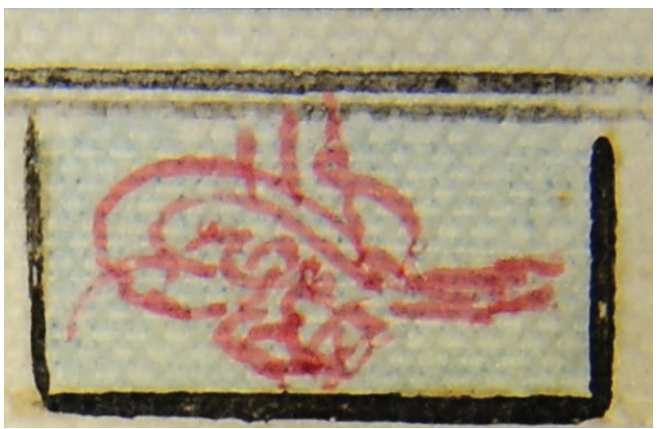

G. 8. Cephe Görünüşü Üzerindeki Tuğranın Detayı (BOA. İ.DH. 1283/100985-1).

Arşiv çiziminde arka ve yan cephelerin görünüşleri yer almamaktadır. Buna karşın kat planları başta pencere sayıları olmak üzere cephelere ilişkin bazı veriler sunmakta ve eski fotoğraflarla kıyaslama imkânı tanımaktadır (G. 10, G. 11). Arka ve yan cephelerin görülebildiği fotoğraflara bakıldığında öncelikle pencere sayılarının planla örtüştüğü anlaşılmaktadır. Sayıların yanı sıra pencereler arası mesafenin de planda belirtildiği şekilde uygulandığı yine yan cephe fotoğraflarında görülmektedir. Kat planlarında gösterildiği gibi ilk beş pencereye kadar aralıklar eşitken, beşinci ve altıncı pencere arasında bu eşitliğin bozulduğu gözlenmektedir. Bunun sebebi içeride bu kısma bölme duvarının yerleştirilmesidir. Yapının arka cephesinin görüldüğü fotoğraflarla alt kat planı kıyaslandığında dört sütunla taşınan revak kısmının uygulanmadığ anlaşılmaktadır. 23 Ağustos 1925 tarihinde Atatürk'ün Çankırı'yı ziyareti sırasında çekilmiş fotoğraflarda, bahsi geçen revak yerine ahşap iki sütun tarafından taşınan bir sundurmanın konulduğu görülmektedir (G. 12, G. 13). Bununla beraber üst kat planında arka cephenin koridora açılan kısmında pencere olarak düşünülen kısmının bir kapıya dönüştürüldüğü de eski fotoğraflar vasıtasıyla tespit edilebilmektedir (G. 9, G. 10, G. 11). Bu bilgiler çerçevesinde projenin küçük değişikliklerle büyük oranda uygulandığını söylemek mümkündür.

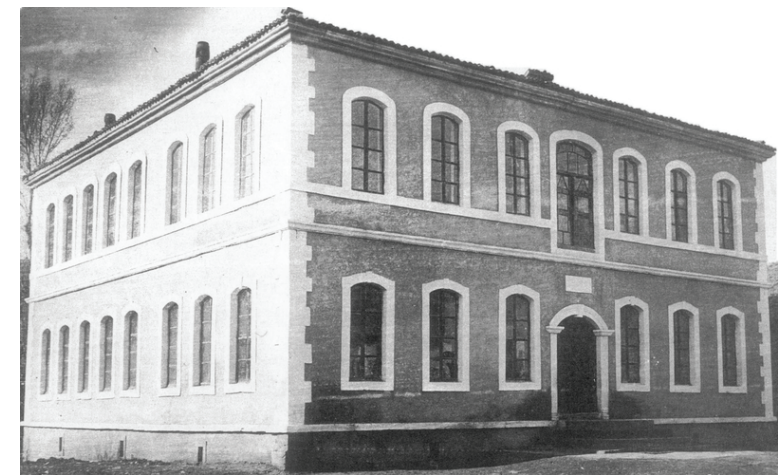

G. 9. Ertuğrul Mektebi Güney ve Doğu (Arka) Cephe Genel Görünüşü (A. Demiröz, 2001). 


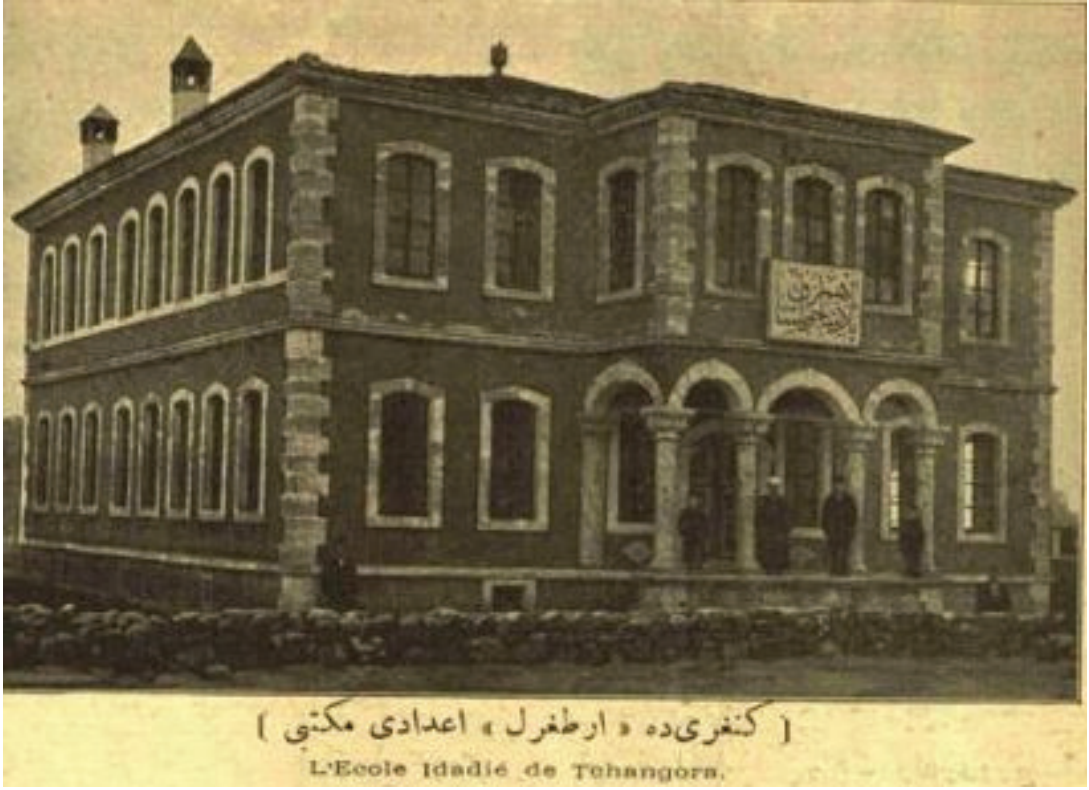

G. 10. Çankırı Ertuğrul İdadi Mektebi (Servet-i Fünûn 284, 8 Ağustos 1312).

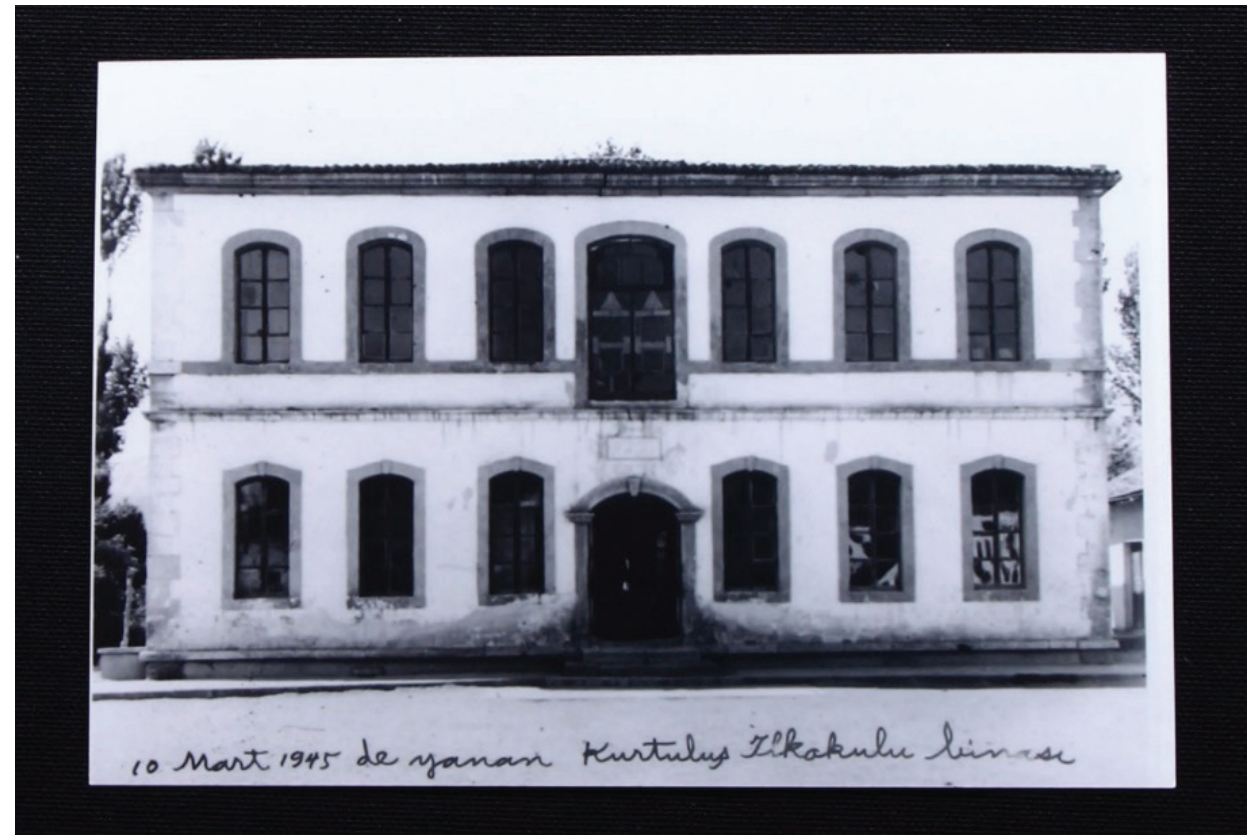

G. 11. Ertuğrul Mektebi’nin Arka Cephe Genel Görünüşü (Çankırı Belediyesi Dr. Rıfkı Kâmil Urga Çankırı Araştırmaları Merkezi Arşivi). 


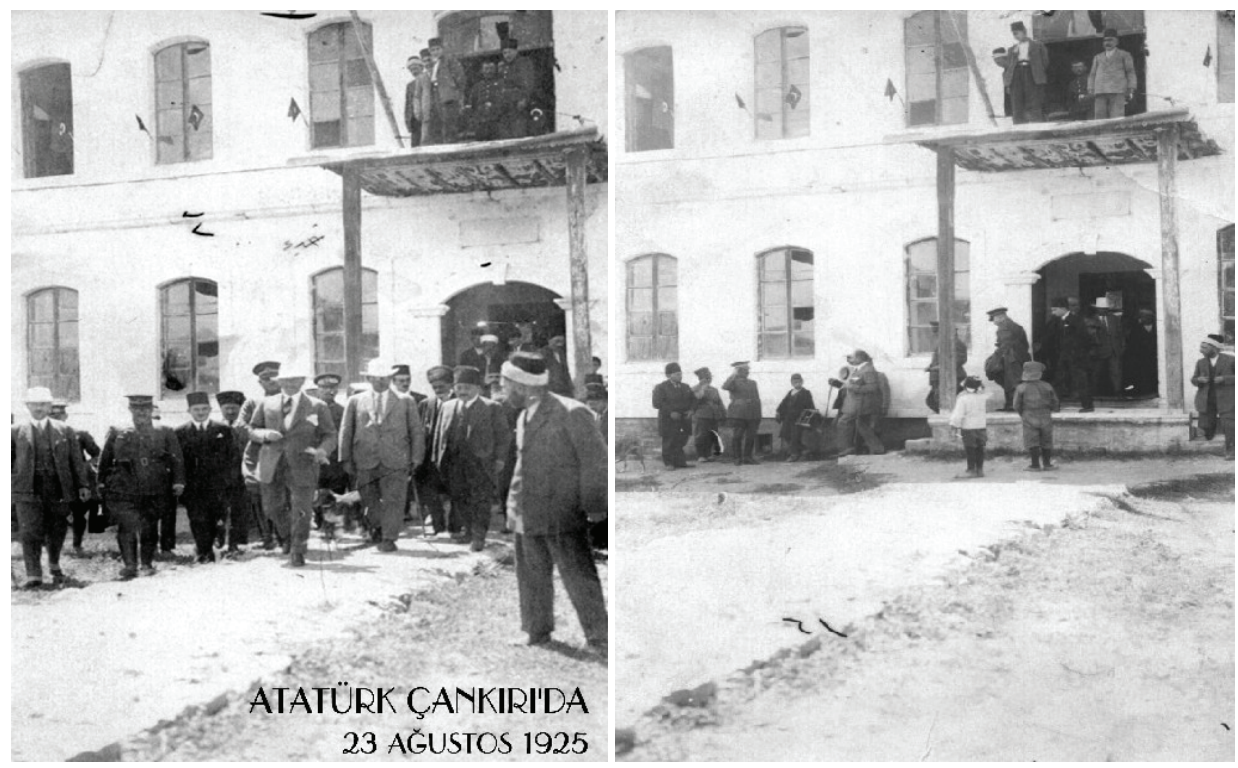

G. 12 ve G. 13. Ertuğrul Mektebi Arka Cephe Görünüşü

(http://www.cankiri.gov.tr/ataturk-cankirida erişim 12.08.2019).

20 Ağustos 1896 tarihli Servet-i Fünûn Dergisi'nde yayınlanan bir başka fotoğrafın alt yazısında yapı, Ertuğrul İdadi Mektebi olarak kaydedilmiştir. Yapıya ilişkin çekilmiş ilk fotoğrafla aynı açıdan alınan görüntüdeki en dikkat çekici husus çıkma üzerine asılmış celi hatlı yazı panosudur. Panoda "Padişahım çok yaşa" ifadesi yazilıdır (G. 10).

Arşiv belgelerinde yapının inşa sürecinin tamamlandığını belirten ifadeleri, Çankırı Müzesi'nde tespit edilen iki kitabeyle doğrulamaktadır. Yapıdan geriye kalan tek somut unsur olarak Çankırı Müzesi'nde muhafaza edilen kitabeler, inşa tarihini kesin olarak ortaya koymaktadır. ${ }^{43}$ Envanter fişlerinde her iki kitabenin de yıkılan Kurtuluş İlkokulu'nun bodrumundan getirildiği yazmaktadır. ${ }^{44} 1077$ envanter numarasıyla kayıtlı kitabenin son satırı, arşiv çizimindeki cephe görünüşüne işlenmiş metinle aynı ifadeleri içermektedir. Taş üzerine iki sütun, altı satır halinde ta' lik hatla yazılıış, dikdörtgen formlu kitabenin transkripsiyonu ve okunuşu şu şekildedir (G. 14):

43 Kitabeleri incelememize izin veren Çankırı Müzesi yetkililerine teşekkürü borç bilirim.

44 Bahsi geçen iki kitabenin günümüzde halen mevcut olan Taş Mektep'e ait olduğu ifade edilmektedir. Balkır, “Çankırı (Merkez İlçe ve Köyleri) Türk Dönemi Mimari Eserleri,” 547-562. 


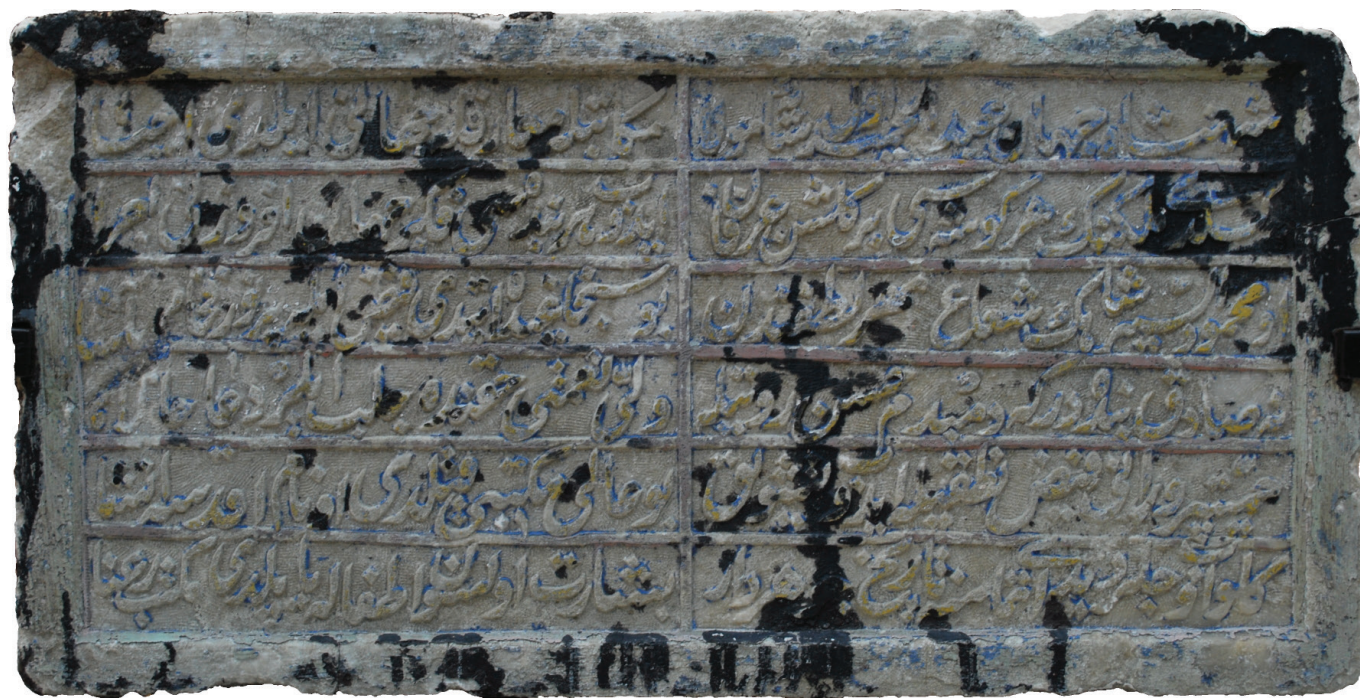

G. 14. Ertuğrul Mektebi'nin Ön Cephesine Ait Çankırı Müzesi'nde Sergilenen İnşa Kitabesi (Remzi Aydın, 2019).

Kitabe Metni:

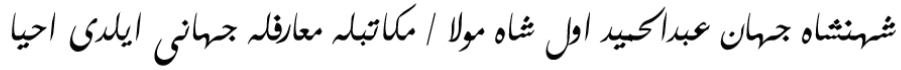

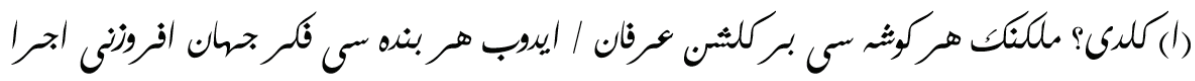

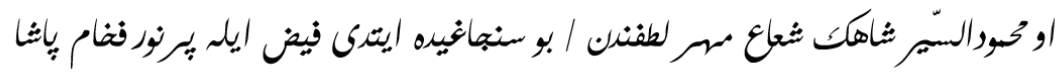

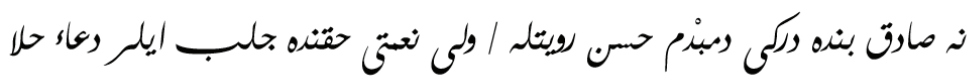

$$
\begin{aligned}
& \text { حيّتيرورانى فيض نتثيله ايروب تثويت / بو عالى مكتبى قيلى او نام اقدس انثا }
\end{aligned}
$$

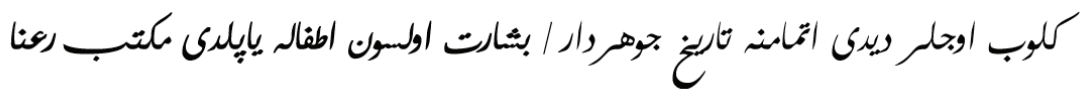

\section{Okunuşu:}

Şehinşah-ı cihan Abdülhamid ol şah-ı Mevla / mekâtîble maârifle cihanı eyledi ihya (E)ğledi? mülkünün her köşesi bir gülşen-i irfan / idüb her bendesi fikr-i cihan efruzunu icra O mahmudü's-seyr şahın şua-yı mihr lütfundan / bu sancağı da itdi feyz ile pür-nur Feham Paşa

Ne sadık bendedir ki dem-be-dem hüsn-i reviyetle / veliniğmeti hakkinda celb eyler dua hala Hamiyyet-perveranı feyz-i nutkuyla idüb teşvik / bu ali mektebi kıldı o nam-ı akdese inşa Gelüb üçler didi itmamına tarih-i cevherdar / beşâret olsun etfale yapıldı mekteb-i rana 
Rakamla belirtilmeyen tarih ibaresinin, kitabenin son satırında ebced ile düşürüldüğü "Gelüb üçler didi itmamına tarih-i cevherdar" mısraından anlaşılmaktadır. Mısradaki "Cevherdar" kelimesi ebced hesaplamasının noktalı harflerin toplanmasiyla elde edilen “mu'cem tarih” ile çıkacağına işaret etmektedir. "Beşâret olsun etfale yapıldı mekteb-i rana" misraindaki kalın vurguyla belirtilen noktalı harflerin toplamı 1306 rakamını vermektedir. İlk satırdaki “gelüb üçler didi itmamına” ifadesi ise çıkan rakam üzerine üç ilave edilmesi gerektiğini belirtmektedir. Ebcedde tamamlama olarak bilinen "ta 'miye” uygulaması doğrultusunda 1306 rakamına 3 ilave edilmesiyle mektebin H. 1309 (M.1891-1892) yılındaki inşa tarihine ulaşılmaktadır. Kitabe ve çizimdeki ifadelerin birbiriyle aynı oluşu kitabenin Ertuğrul Mektebi'ne ait olduğunu ve 1891-1892 y1lında inşa edildiğini kesin olarak ortaya koymaktadır (G. 15). Kitabe ile belgelerin birbirini doğruladığı bir başka husussa mektebin yapımına vesile olan kişinin Feham Hasan Paşa olduğudur. Ancak kaynaklarda mektebin 1893 yılında Abdulvahab Paşa tarafından yaptırıldığg belirtilmektedir. ${ }^{45}$

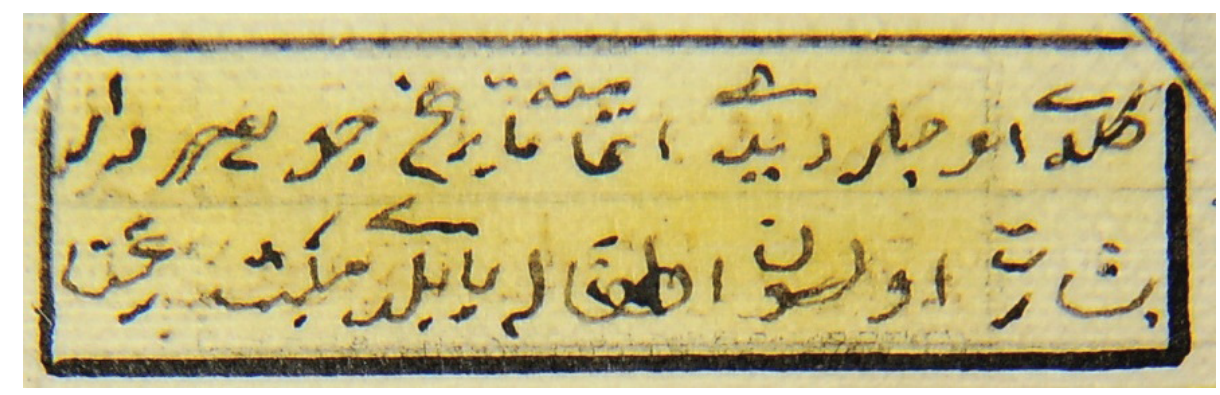

G. 15. Cephe Görünüşü Üzerindeki Kitabe Metninin Detay1 (BOA. İ.DH. 1283/100985-1).

Çankırı Müzesi envanterine 1078 numarayla kayıtlı diğer bir kitabenin de Ertuğrul Mektebi'ne ait olma ihtimali oldukça güçlüdür. 1077 envanter numaralı kitabenin yapının ön cephesinde olduğu eski fotoğraflarda görülmemekle beraber arşiv çiziminde son satırının işlenmesiyle kesinleşmektedir. Fotoğraflardan yapının arka cephesinde giriş kapısının üzerinde bir kitabenin daha var olduğu tespit edilebilmektedir (G. 9, G. 11, G. 12, G. 13). Üzerindeki yazısı fotoğraflardan okunamayan bu kitabenin boyutu ve formu itibarıyla müzede 1077 numarayla kayıtlı yazıt olduğu görüşü ileri sürülebilir. Kitabenin içeriği de bu görüşü destekler niteliktedir. Taş üzerine ta'lik hatla dört satır olarak işlenmiş olan dikdörtgen formlu kitabenin transkripsiyonu ve okunuşu şu şekildedir (G. 16).

45 Demiröz, 1893-1969 Fotoğraflarla Çankırı, 42; Topçubaşı, “19. Yüzyılda Kastamonu Eyaleti’nde Kamu Yapıları ve Yeniden Kullanım Sorunları," 329. 


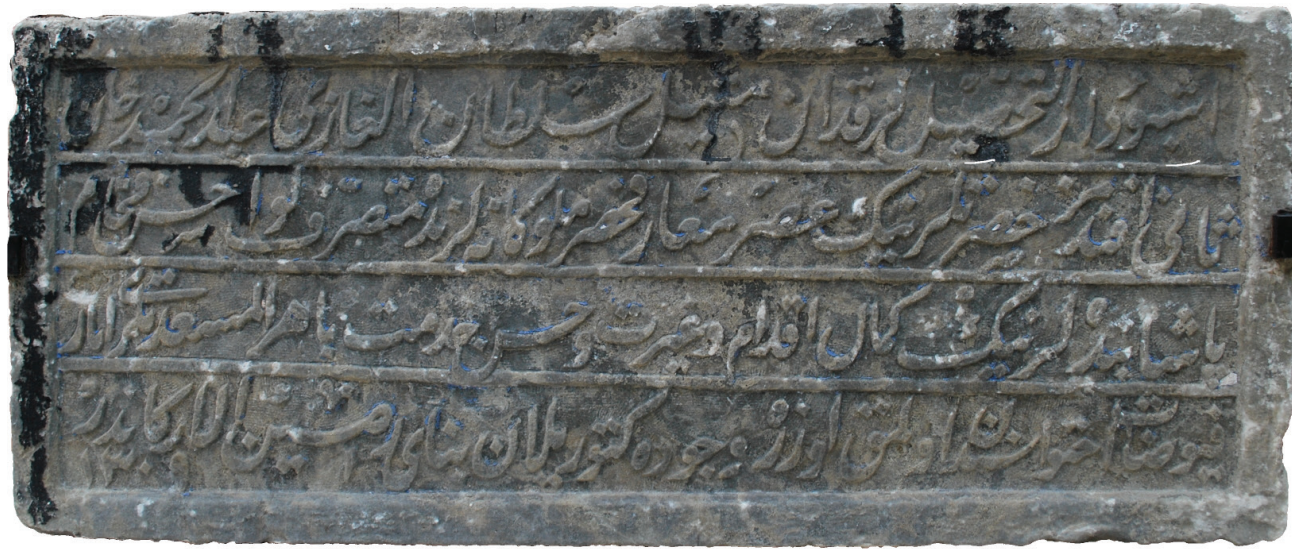

G. 16. Ertuğrul Mektebi’nin Arka Cephesine Ait Çankırı Müzesi'nde Sergilenen İnşa Kitabesi (Remzi Aydın, 2019).

Kitabe Metni:

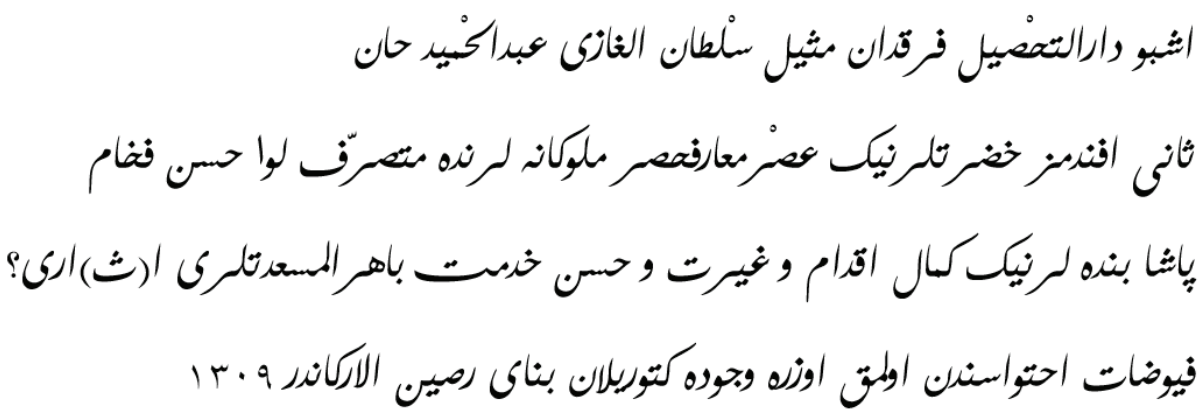

Okunuşu:

İsbu darü't-tahsil firakdan mesil sultanü'l-gazi Abdülhamid han-l

Sânî efendimiz hazretlerinin asr-ı maârif-hasr mülûkânelerinde mutasarrıf-ı liva Hasan Feham

Paşa bendelerinin kemal-i ikdam ve gayret ve hüsn-i hidmet bahirü'l-mesadetleri a(s)ar-l? Füyûzat ihtivasından olmak üzere vücuda getürilen bina-yı rasinü'l-erkandır 1309

Kitabeden mektebin 1891-1892 yılında Çankırı Mutasarrıfı Feham Hasan Paşa'nın katkılarıyla inşa ettirildiği anlaşılmaktadır. İlk kitabeyle aynı yerden getirilişi, aynı içeriğe sahip oluşu ve ebced ile çıkarılan H. 1309 tarihini rakamla taşıyor olması bu kitabenin de Ertuğrul Mektebi'ne ait olduğunu iddia etmemize imkân tanımaktadır. 
Kaynaklarda mektebin 1893 yılında inşa ettirildiği belirtilmektedir. ${ }^{46}$ Kitabeler ise bu tarihin 1891-1892 y1lı olduğunu ortaya koymaktadır. Belgeler ise inşa tarihinin Haziran 1892 itibarıyla tamamlandığını göstermektedir. ${ }^{47}$ Bu bilgiler çerçevesinde kitabelerdeki hicri-miladi tarih dönüşümünden kaynaklanan bir yıl aralığının belgelerden hareketle 1892 olarak dikkate alınması gerektiği ortaya çıkmaktadır. Bu veriler doğrultusunda Ertuğrul Mektebi’nin 1892 y1lında tamamlanarak eğitim hizmetine hazır hâle geldiği kesinleşmektedir.

\section{Değerlendirme}

Geçirdiği yangın sonrasında ortadan kalkarak günümüze ulaşamayan yapı, ancak eski fotoğraflar ve arşiv çizimlerinden hareketle değerlendirilme imkânına sahiptir. Ne projede ne de belgelerde mektebin kim tarafından tasarlandığına dair herhangi bir kayıt bulunmamaktadır. Bununla beraber 19. yüzyılın sonlarından itibaren taşradaki imar faaliyetlerinin büyük bir bölümünü liva veya belediye bünyesinde görev yapan mühendislerin yürüttüğü de bilinen bir gerçektir. ${ }^{48}$ Kastamonu Vilayet Salnamesi’nin Çankırı ile ilgili bölümlerinde 1889-1893 yılları arasında Nafıa Dairesi ve Tarik Komisyonu'nda Mehmed Ali Bey'in mühendis olarak görev yaptığ 1 kayıtlıdır. ${ }^{49}$ Mehmed Ali Bey'in bu tasarımı gerçekleştirebilecek bilgi ve donanıma sahip olduğu Osmanlı Arşivinde tespit edilen plan ve projelerden anlaşılmaktadır. Tespit edilebilen proje tasarımlarından bazıları, Çankırı Hapishanesi (1894), Çankırı Hükümet Konağı (1894), Avanos Köprüsü (1895-1897), Avanos Hapishanesi (1897) ve Kayseri İdadisi (1899) şeklinde sıralanmaktadır. ${ }^{50}$ Bu çerçevede okulun tasarımını, 1889-1895 yılları arasında Çankırı'da görev yapmış olan Mehmed Ali Bey'in gerçekleştirme olasılığ oldukça yüksektir.

Osmanlı Arşivinde bu yapıya ait inşa defteri henüz tespit edilemediğinden yapının inşasında hangi malzemelerin kullanıldığı tam olarak bilinememektedir. Ancak eski fotoğraflardan ve cephe çiziminden anlaşıldığına göre yapının cephelerinde kullanılan ana malzeme düzgün kesme taştır. Ön cephedeki revak sütunlarınınsa mermer-taş olması muhtemeldir. Örtüde ise yöre ve inşa edildiği döneme uygun olarak alttan kaplamalı ahşap tavan tercih edilmiş olmalıdır. Çatı onarımında kullanılan malzemelerse arşiv belgelerinde görüldüğü üzere kum, kireç ve kiremittir.

İbtidâi ve rüşdiyye olarak tasarlanan yapı, zaman içerisinde ihtiyaca binaen idadi olarak da hizmet vermiştir. Arşiv çizimlerindeki alt ve üst kat planlarına göre yapı, or-

46 Demiröz, 1893-1969 Fotoğraflarla Çankırı, 42; Topçubaşı, “19. Yüzyılda Kastamonu Eyaleti’nde Kamu Yapıları ve Yeniden Kullanım Sorunları," 329.

47 BOA. İ.DH. 1283/100985-2.

48 Remzi Aydın, “Osmanlı İmparatorluğu’nda Onarım Faaliyetleri: Kayseri Örneği”’ (Doktora tezi, Erciyes Üniversitesi, 2013), 476-479.

49 Türkoğlu, Sâlnâmelerde Çankırı, 328, 391.

50 Remzi Aydın, “Mühendis Mehmed Ali Bey’in Avanos’taki Projeleri,” Ístem 32 (2018), 381. 
tadaki koridor esas alınarak iki yanında sıralanmış mekânlardan meydana gelmektedir. Üst kat koridorunun dışa taşırılmasıyla içeride kazanılan ilave dershane dışında alt ve üst katlar simetrik plandadır. Koridor esaslı plan şemasının uygulandığı yapılar, Fatih, Kocamustafapaşa, Beşiktaş, Gülhane, Soğukçeşme, Kasımpaşa, Erzincan, Kastamonu, Edirne, Bursa, Trabzon askeri rüşdiyye mektepleri olarak sıralanabilir. ${ }^{51} \mathrm{Bu}$ yap1ların tamamında plan şemasını belirleyen ana unsur koridordur. Bu şemada koridor, kimi zaman tek başına girişle aynı aksta veya paralel olarak uzanırken kimi zaman da her iki koridor ortada birbirini keserek iki yönde uzanabilmektedir. Bu plan şemas1 sadece rüşdiyye mekteplerinde değil, ibtidai ${ }^{52}$ ve idadi mektepleri ${ }^{53}$ ile hükümet konağ $1^{54}$, hapishane ${ }^{55}$ ve askeri binalar ${ }^{56}$ gibi farklı yapı türlerinde de görülmektedir.

Bodrum kat üzerine iki kat olarak inşa edilen Ertuğrul Mektebi cephe özellikleri bakımından dönemin hâkim anlayışı neo-klasik üslubu sergilemektedir. Yapının planında hâkim olan simetrik kurgu, tüm cephelerde de görülmektedir. Birbirine yuvarlak kemerlerle bağlanmış sütunların taşıdığı revak ve üzerindeki çıkma, ön cephenin merkezini oluşturmaktadır. Dişa taşkın basık pencere kemeri, kemer kilit taşı ve söveler ile köşe taşları gibi vurgulayıcı unsurlar, sadece önde değil yapının tüm cephelerinde uygulanmıştır. Profilli saçak ve kat silmeleri de cepheyi dört yönden kuşatmaktadır. Ç1kma cephesinin ortasında yer alan tuğra da Sultan II. Abdülhamid döneminde inşa edilen yapıların karakteristik unsurlarından biridir. ${ }^{57}$ Cephe özellikleri yukarıda sıralanan yapıların hemen hepsiyle benzerlik sergilemektedir. Planda olduğu gibi cephede de kamu yapılarının neredeyse tamamı için belirli bir üslup birliğinin yakalandı ğı

51 Esma İgüs, "II. Abdülhamid Dönemi Eğitim Sistemi, Eğitim Yapıları ve Askeri Rüşdiyeler” (Doktora tezi, Y1ldı Teknik Üniversitesi, 2008), 363-364, 372-373, 379-380, 381-382, 384-385, 394-395, 403-404, 408409, 410-411, 415-416, 423-424.

52 Yıldıray Özbek, “Tanzimat Sonrası Osmanlı Eğitim Yapıları,” Osmanlı Sanatında Değişim ve Dönüşüm, ed. Ayşe Budak, Muzaffer Yılmaz (Konya: Literatürkacademia Yayınları, 2019), 320-326.

53 Burcu Özgüven, "İdadi Binaları," Tarih ve Toplum 82 (1990), 44-47; Osman Doğan, Sultan II. Abdülhamid Han Devri Osmanlı Mektepleri, ed. Ömer Faruk Yılmaz (İstanbul: Çamlıca Yayınları, 2007); Şevki Duymaz, “II. Abdülhamid Dönemi Eğitim Yapıları,” Devr-i Hamid Sultan II. Abdülhamid 5, ed. Metin Hülagu, vd. (Kayseri: Erciyes Üniversitesi Yayınları, 2011), 174-176; Lütfiye Göktaş Kaya ve Muhammet Özkurt, "19. 20. Yüzyıl Osmanlı Dönemi Eğitim Yapıları: Kastamonu Merkez Mekteb-i İdadi, Mekteb-i Sanayi, Rum Mektebi,” Akademik Sosyal Araştırmalar Dergisi 73 (2018), 37-56.

54 Nurcan Yazıcı Metin, “Son Dönem Osmanlı Mimarlığının Başat Yapıları: Hükümet Konakları,” Osmanlı Sanatında Değişim ve Dönüşüm, ed. Ayşe Budak, Muzaffer Yılmaz (Konya: Literatürkacademia Yayınları, 2019), 271-315; Nurcan Yazıcı Metin, Tanzimat’tan Cumhuriyet'e Hükümet Konaklarının İnsa Süreci ve Mimarisi Devlet Kapısı (İstanbul: Kitabevi Yayınları, 2019), 126-127.

55 Remzi Aydın, "Mimar Kemâleddin Bey’in Hapishane Projeleri," Osmanlı Sanatında Değişim ve Dönüşüm, ed. Ayșe Budak, Muzaffer Yılmaz (Konya: Literatürkacademia Yayınları, 2019), 11-36.

56 Topçubaşı, “19. Yüzyılda Kastamonu Eyaleti’nde Kamu Yapıları ve Yeniden Kullanım Sorunları,” 533; Sultan Murat Topçu, "Yozgat-Akdağmaden Redif Teşkilatı Debboy Binası,” Turkish Studies 9/10 (2014), 1023-1038; Zeynep Aytekin, “Kastamonu İli Taşköprü İlçesindeki Türk Devri Yapıları” (Yüksek lisans tezi, Erciyes Üniversitesi, 2016), 432-441.

57 İgüs, “II. Abdülhamid Dönemi Eğitim Sistemi, Eğitim Yapıları ve Askeri Rüşdiyeler,” 235; Esma İgüs, “II. Abdülhamid Dönemi Askeri Rüştiyelerini Mimari Planları Üzerinden Okumak," Sosyal ve Liberal Bilimlerde Yeni Yönelimler Sempozyumu Bildiri Kitabı I, ed. Hasan Babacan, Sevilay Özer (Ankara: Gece Kitaplığı, 2016), 304. 
dönem yapılarından anlaşılmaktadır. Yapının ön cephesindeki tuğra, sütunlu revak, cephedeki profilli silmeler, pencerelerin dışa taşırılmış kemer ve kilit taşlarıyla köşe taşları dışında Ertuğrul Mektebi’nde süsleme unsuru görülmemektedir.

\section{Sonuç}

Osmanlı modernleşmesinin eğitim alanında 18. yüzyılda başlayan ilk aşaması, Tanzimat ve Islahat dönemlerinde belirli bir mesafe kaydetmiş ve 19. yüzyılın son çeyreğinde, özellikle Sultan II. Abdülhamid döneminde büyük bir ivme kazanmıştır. $\mathrm{Bu}$ ivmenin somut örneklerini iktidarı boyunca imparatorluk sathında inşa edilen eğitim yapılarının sayısından anlamak mümkündür. Eğitim meselesinin önemli bir gündem hâline geldiği Osmanlı Arşivindeki belgelerden açıkça anlaşılmaktadır. Osmanlı bürokratları merkezi idarenin eğitim politikasına uygun olarak görev yaptıkları bölgelerde vatandaşları mektep yapımına teşvik etme noktasında önemli bir rol oynamıştır. Bu doğrultuda devlet-vatandaş iş birliğiyle pek çok eğitim binası inşa edilmiştir. Çankırı'da günümüze ulaşamayan Ertuğrul Mektebi de taşradaki eğitim hamlesinin bir parçası olarak inşa edilen yapılardan biridir.

Devlet ve iktidar ideolojisinin yerleştirilmesindeki en önemli araçlardan biri olan eğitime Sultan II. Abdülhamid'in özel bir önem verdiği anlaşılmaktadır. Sultan pek çok alanda olduğu gibi inşa faaliyetlerini de "hafızalara yerleşmek" amacıyla kullanmıştır. Bu bağlamda yöneticilere, padişahın tahta çıkış ve doğum günleri şerefine, görev yaptıkları yerlerde ihtiyaç duyulan binaları inşa etmeleri yönünde talimatlar da verilmiştir. İnşası tamamlanan binaların açılışlarının ise bu özel günlere denk getirilmesi özellikle belirtilmiştir. Nitekim Çankırı'da açılan ilk rüşdiyye mekteplerinin açılış töreni padişahın tahta çıkış gününe denk getirilmiş ve törende padişaha dualar edilmiştir. Her yılın 13 Haziran'ında kutlanan cülus (tahta çıkış) yıldönümünden bir gün önce, 12 Haziran 1892 tarihinde, Ertuğrul Mektebi’nin inşasının tamamlanma haberinin gönderilmesi de rastlantı olmasa gerektir.

Ertuğrul Mektebi'nde çıkma cephesinin tam ortasına yerleştirilmiş tuğra, sultanın kamusal görünürlüğünü somutlaştıran bir unsur olarak karşımıza çıkmaktadır. Servet-i Fünûn Dergisi'nde yayımlanan bir fotoğrafta mektebe asılan "padişahım çok yaşa" levhasıysa Sultan imgesinin hafızalardaki yerini vurgulayan bir başka uygulamadır. Pek çok yapıya kendi adının verilmesine onay veren Sultan II. Abdülhamid, Çankırı'da inşa edilen mektebe atası Ertuğrul Gazi'nin adının verilmesini "cedd-i âlây-ı hazret-i hilâfet-penâhî firdevs-âş̧iyan Ertuğrul Gazi hazretlerinin nam-ı celâdet-i ittisam-ı âlîlerine nisbetle tesmiye olunması" ifadeleriyle uygun görmüştür. Sultanın büyük atasına duyduğu saygı ve minnetin bir nişanesi olarak yapının Ertuğrul Mektebi olarak adlandırılmasını istediği aşikârdır. Bununla beraber Sultan, cadde, sokak, bina, yerleşim yerleri ve hatta askeri birliklere kendisi ve ceddinin isimlerini 
vererek hâkimiyetini ve imajını zihinlerde mutlak hâle getirmeye çalışmıştır. Mektepten günümüze kalan tek bakiye durumundaki kitabelerde, Sultanın eğitime verdiği önem "mekâtîble maârifle cihanı eyledi ihya, (e) ğledi? mülkünün her köşesi bir gülşen-i irfan, efendimiz hazretlerinin asr-ı maârif-hasr mülûkânelerinde” ifadeleriyle vurgulanmıştır. Aynı kitabeler, Hasan Feham Paşa'nın şahsında bürokratların eğitime verdiği çabaları ortaya koyan ifadelerle doludur.

Sonuç olarak, Osmanlı modernleşme çağında yeni eğitim anlayışıyla hizmet vermek üzere inşa edilen ancak günümüze ulaşamayan Ertuğrul Mektebi’nin yapım tarihi, plan, cephe ve süsleme özellikleri arşiv belgeleri üzerinden tespit edilmiştir.

\footnotetext{
Hakem Değerlendirmesi: Dış bağımsız.

Çıkar Çatışması: Yazar çıkar çatışması bildirmemiştir.

Finansal Destek: Yazar bu çalışma için finnansal destek almadığını beyan etmiştir.

Peer-review: Externally peer-reviewed.

Conflict of Interest: The author has no conflict of interest to declare.

Grant Support: The author declared that this study has received no financial support.
}

\section{Kaynakça/References}

Aktaş, Cahit. "Belgeler Işı̆̆ında Kengırı (Çankırı) Kız Mektebi.” Çankırı Araştırmaları Dergisi 3 (2008): 73-84.

Aydın, Remzi. “Osmanlı İmparatorluğu'nda Onarım Faaliyetleri: Kayseri Örneği.” Doktora tezi, Erciyes Üniversitesi, 2013.

Aydın, Remzi. “Mühendis Mehmed Ali Bey’in Avanos’taki Projeleri.” İstem 32 (2018): 357-383.

Aydın, Remzi. "Mimar Kemâleddin Bey'in Hapishane Projeleri," Osmanlı Sanatında Değişim ve Dönüşüm, Ed. Ayşe Budak, Muzaffer Yılmaz. Konya: Literatürkacademia Yayınları, 2019, 11-36.

Aytekin, Zeynep. “Kastamonu İli Taşköprü İlçesindeki Türk Devri Yapıları.” Yüksek lisans tezi, Erciyes Üniversitesi, 2016.

Demiröz, Aydın. 1893-1969 Fotoğraflarla Çankırı. Çankırı: Çankırı Belediyesi Kültür Yayınları, 2001.

Doğan, Osman. Sultan II. Abdülhamid Han Devri Osmanlı Mektepleri. Ed. Ömer Faruk Y1lmaz. İstanbul: Çamlıca Yayınları, 2007.

Duymaz, Şevki. “II. Abdülhamid Dönemi Eğitim Yapıları.” Devr-i Hamid Sultan II. Abdülhamid 5. Ed. Metin Hülagu, vd. Kayseri: Erciyes Üniversitesi Yayınları, 2011, 169-187.

Eken, Galip. “19. Yüzyılda Sonlarında Çankırı'da Eğitime Dair.” Cumhuriyet Üniversitesi Edebiyat Fakültesi Sosyal Bilimler Dergisi 37/1 (2013): 107-116.

Erdoğdu, Teyfur. "Maarif-i Umumiyye Nezareti Teşkilatı I.” Ankara Üniversitesi Siyasal Bilgiler Fakültesi Dergisi, 51/1 (1996): 183-247.

Erdoğdu, Teyfur. "Maarif-i Umumiyye Nezareti Teşkilatı II.” Ankara Üniversitesi Siyasal Bilgiler Fakültesi Dergisi, 52/1 (1997): 247-285.

Ergin, Osman Nuri. Türk Maarif Tarihi. İstanbul: Eser Kültür Yayınları, 1977. 
Göktaş Kaya, Lütfiye ve Muhammet Özkurt. “19.-20. Yüzyıl Osmanlı Dönemi Eğitim Yapıları: Kastamonu Merkez Mekteb-i İdadi, Mekteb-i Sanayi, Rum Mektebi.” Akademik Sosyal Araştırmalar Dergisi 73 (2018): 37-56.

İgüs, Esma. “II. Abdülhamid Dönemi Eğitim Sistemi, Eğitim Yapıları ve Askeri Rüşdiyeler.” Doktora tezi, Yıldız Teknik Üniversitesi, 2008.

İgüs, Esma. "II. Abdülhamid Dönemi Askeri Rüştiyelerini Mimari Planları Üzerinden Okumak”, Sosyal ve Liberal Bilimlerde Yeni Yönelimler Sempozyumu Bildiri Kitabı I, 293-315. Ed. Hasan Babacan, Sevilay Özer. Ankara: Gece Kitaplığı, 2016.

Kodaman, Bayram. Abdülhamid Devri Eğitim Sistemi. Ankara: Türk Tarih Kurumu Yayınları, 1999.

Metin Yazıcı, Nurcan. "Son Dönem Osmanlı Mimarlığının Başat Yapıları: Hükümet Konakları.” Osmanlı Sanatında Değişim ve Dönüşüm, 271-315. Ed. Ayşe Budak, Muzaffer Yılmaz. Konya: Literatürkacademia Yayınları, 2019.

Metin Yazıc1, Nurcan. Tanzimat'tan Cumhuriyet'e Hükümet Konaklarının İnşa Süreci ve Mimarisi Devlet Kapısı. İstanbul: Kitabevi Yayınları, 2019.

Özbek, Yıldıray. “Tanzimat Sonrası Osmanlı Eğitim Yapıları.” Osmanlı Sanatında Değişim ve Dönüşüm. Ed. Ayşe Budak, Muzaffer Yılmaz. Konya: Literatürkacademia Yayınları, 2019, 317-335.

Özcan Balkır, Betül. “Çankırı (Merkez İlçe ve Köyleri) Türk Dönemi Mimari Eserleri.” Doktora tezi, Gazi Üniversitesi, 2018.

Özgüven, Burcu. "İdadi Binaları.” Tarih ve Toplum 82 (1990): 44-47.

Topçu, Sultan Murat. "Yozgat-Akdağmaden Redif Teşkilatı Debboy Binası." Turkish Studies 9/10 (2014): 1023-1038.

Topçubaşı, Mine. “19. Yüzyılda Kastamonu Eyaleti’nde Kamu Yapıları ve Yeniden Kullanım Sorunları.” Doktora tezi, İstanbul Teknik Üniversitesi, 2009.

Türkoğlu, Ömer. Sâlnâmelerde Çankırı. Çankırı: Çankırı Valiliği Yayınları, 1999.

Başbakanlık Osmanlı Arşivi (BOA), Sadaret Mühimme Kalemi Evrakı (A.MKT.MHM.) 417/16, 29 Rebiülahir 1285 (19 Ağustos 1868); 426/30, 22 Receb 1285 (8 Kasım 1868); Dahiliye Mektubi Kalemi (DH.MKT.) 121/33, 7 Rebiülahir 1311 (18 Ekim 1893); 347/39, 26 Şaban 1312 (22 Şubat 1895); İrade Dahiliye (İ.DH.) 1283/100985, 1 Zilhicce 1309 (27 Haziran 1832); Maarif Nezareti Mektubi Kalemi (MF.MKT.) 146/29, 6 Muharrem 1310 (31 Temmuz 1892), 365/3, 10 Rebiülevvel 1315 (9 Ağustos 1897), 587/53, 11 Receb 1319 (24 Ekim 1901); Şura-y1 Devlet (ŞD.) 1640/1, 24 Zilkade 1287 (15 Şubat 1871).

https://www.loc.gov/item/2001700265/ Erişim 12.08.2019.

http://www.cankiri.gov.tr/ataturk-cankirida Erişim 12.08.2019. 
